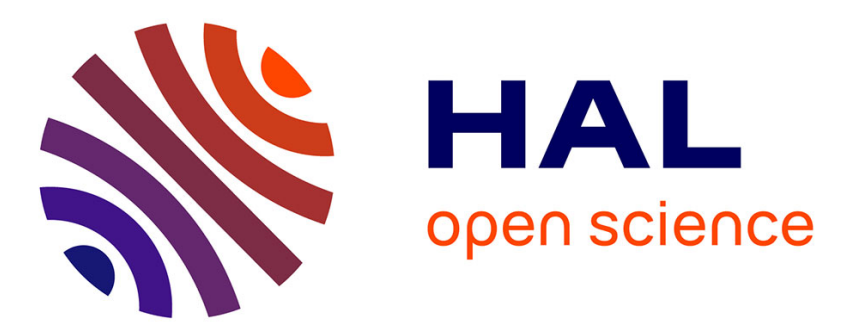

\title{
How to tailor heat-induced whey protein/ $\kappa$-casein complexes as a means to investigate the acid gelation of milk-a review
}

Morand, Fanny Guyomarc'H, Marie-Hélène Famelart

\section{- To cite this version:}

Morand, Fanny Guyomarc'H, Marie-Hélène Famelart. How to tailor heat-induced whey protein/ $\kappa$ casein complexes as a means to investigate the acid gelation of milk-a review. Dairy Science \& Technology, 2011, 91 (2), pp.97-126. 10.1007/s13594-011-0013-x . hal-00930572

\section{HAL Id: hal-00930572 \\ https://hal.science/hal-00930572}

Submitted on 1 Jan 2011

HAL is a multi-disciplinary open access archive for the deposit and dissemination of scientific research documents, whether they are published or not. The documents may come from teaching and research institutions in France or abroad, or from public or private research centers.
L'archive ouverte pluridisciplinaire HAL, est destinée au dépôt et à la diffusion de documents scientifiques de niveau recherche, publiés ou non, émanant des établissements d'enseignement et de recherche français ou étrangers, des laboratoires publics ou privés.

$$
\text { Copyright }
$$




\title{
How to tailor heat-induced whey protein/K-casein complexes as a means to investigate the acid gelation of milk—a review
}

\author{
Marion Morand • Fanny Guyomarc'h • \\ Marie-Hélène Famelart
}

Received: 3 June 2010 /Accepted: 2 September 2010 /

Published online: 18 March 2011

(C) INRA and Springer Science+Business Media B.V. 2011

\begin{abstract}
The heat treatment of milk greatly improves the acid gelation of milk and is therefore largely applied in yoghurt manufacture. During the heat treatment, soluble and micelle-bound whey protein/K-casein complexes are produced in milk. The complexes and their physico-chemical properties have been held responsible for the early gelation point, the increased final firmness and for the serum retention capacity of the acid gels made of heated milk. They are suspected to bring new functionalities to the casein micelles and to help the formation of interactions when building the gel network. In order to investigate the type of interactions that the complexes can affect throughout the acid gelation of milk, an original strategy would be to control the physico-chemical properties of the whey protein/K-casein soluble complexes and to use them as vectors to modify the possible interactions in the milk. In that perspective, the different physico-chemical properties of the whey protein/K-casein soluble complexes that are thought to significantly affect the acid gelation behaviour of the casein micelles are listed. Then, the physical, chemical and biological means that could possibly be applied to the formation of complexes in order to modulate each of the targeted property are reviewed and evaluated. In order to open a large choice for future investigation, these methods were found in a larger literature resource than milk, including other protein systems like model whey protein solutions or non-dairy globular protein systems. The food-compatible
\end{abstract}

M. Morand · F. Guyomarc'h • M.-H. Famelart $(\bowtie)$

INRA, UMR1253, Science et Technologie du Lait et de l'Euf, 65 rue de St Brieuc,

35042 Rennes cedex, France

e-mail: marie-helene.famelart@rennes.inra.fr

M. Morand · F. Guyomarc'h · M.-H. Famelart

AGROCAMPUS OUEST, UMR 1253, Science et Technologie du Lait et de l'CEuf, 65 rue de St Brieuc, 35042 Rennes cedex, France 
character of some of these means is indicated, for their potential technological interest.

\section{乳清蛋白/ $\mathrm{\kappa}$-酪蛋白复合物与牛奶的酸凝固—综述}

摘要 牛奶经热处理后可以大大改善牛奶的酸凝固过程, 因此热处理广泛应用 于酸奶的生产中。热处理会在乳中产生可溶性蛋白与酪蛋白胶束结合的乳清 蛋白/ $\kappa^{-}$酪蛋白复合物。这些复合物和他们的物理化学性质会导致牛乳凝固点 提前、形成凝胶的硬度提高, 以及热处理牛乳形成酸凝胶的持水力增强。这种 处理方式有可能改变酪蛋白胶束的功能特性, 可能有助于凝胶网络的形成。为 了研究复合物对乳酸凝固过程的影响以及相互作用的类型, 首先要控制可溶性 乳清蛋白 $/ \kappa-$ 酪蛋白复合物的物理化学性质，然后以这种复合物为模型来研究 乳中可能的相互作用。本文列出了不同物理化学性质的可溶性乳清蛋白 $/ \kappa-$ 酪 蛋白复合物对酪蛋白胶束酸凝固性质的影响。此外, 为调整每个目标产物的特 性，本文综述和评价了所形成复合物的物理、化学和生物学意义。为了对将来 研究提供更多的选择性, 本文对乳以外的文献也进行了综述, 如模拟乳清蛋白 溶液或者非乳球蛋白体系等其他类型的蛋白质体系。并指出了这些体系与食 物相对应的特性，以及潜在的应用前景。

Keywords Acid gel $\cdot$ Complex $\cdot$ Heat treatment $\cdot$ Whey proteins $\cdot$ Casein

关键词 酸凝胶. 热处理·乳清蛋白・酪蛋白

\section{Introduction}

Milk proteins, which weight for $33-35 \mathrm{~g} . \mathrm{kg}^{-1}$ of total skim milk, are essential to the formation of dairy gels like cheese or yoghurt. Milk proteins commonly fall into the whey proteins, accounting for $7-8 \mathrm{~g} \cdot \mathrm{kg}^{-1}$ and found in globular soluble form; and the caseins, accounting for 26-28 g. kg-1 and found in colloidal assemblies called the casein micelles (Walstra and Jenness 1984). In bovine milk, the two major whey proteins are the $\beta$-lactoglobulin $\left(\beta-\mathrm{LG}, 2-4 \mathrm{~g} \cdot \mathrm{kg}^{-1}\right)$ and $\alpha$-lactalbumin ( $\alpha$-LA, $\sim 1.5 \mathrm{~g} . \mathrm{kg}^{-1}$ ), followed by the immunoglobulins, bovine serum albumin (BSA) and lactoferrin. The caseins are the $\alpha_{\mathrm{s} 1}$-casein, $\beta$-casein (9-10 g. kg ${ }^{-1}$ each), $\mathrm{k}$-casein and $\alpha_{\mathrm{s} 2}$-casein (2-4 g. $\mathrm{kg}^{-1}$ each; Cayot and Lorient 1998). In all types of dairy gels, the casein micelles are the essential building blocks of the protein network (de Kruif 1998; Holt and Horne 1996; van Vliet et al. 1989). In their native form, the whey proteins barely contribute to gelation, neither through acidification nor renneting. However, it is well-known that denaturation of the whey proteins largely accounts for the effect of heat treatment on the acid gelation of milk. Typically, acidified milk that had been heated at 85-95 ${ }^{\circ} \mathrm{C}$ for several minutes starts to gel at a higher $\mathrm{pH}$ value than unheated milk and yields an acid gel with increased elastic modulus and higher water retention capacity (Lucey et al. 2000, 1997a; van Vliet et al. 2004).

In the literature, different reviews exist that thoroughly describe the heatinduced denaturation and aggregation of the whey proteins, either in model solutions of $\beta$-LG or of whey protein isolates (de Wit 2009; Foegeding et al. 2002) or in milk (Donato and Guyomarc'h 2009). In essence, the whey proteins 
unfold as soon as the temperature exceeds $\sim 60{ }^{\circ} \mathrm{C}$ then interact through hydrophobic interactions and thiol/disulphide exchanges to yield heat-induced whey protein complexes. In milk, these complexes also involve the cysteinecontaining $\mathrm{K}$-casein and can be found both in the form of soluble complexes and in the form of micelle-bound complexes (Anema 1997; Anema and Li 2000; Donato and Dalgleish 2006; Guyomarc'h et al. 2003b). However, despite the increased knowledge on the structural and physico-chemical properties of these heat-induced whey protein/K-casein complexes, little is known of the actual mechanism through which they can affect the onset of gelation and the final mechanical properties of the acid milk gel. In their review, Donato and Guyomarc'h (2009) suggested that the whey protein/K-casein complexes bring new functionalities to the casein micelles, either through modifying their surface as to increase the attraction-torepulsion resultant interaction or through acting as spacers that bridge the micelles together and sustain the gel's microstructure. In order to investigate these hypotheses, one original approach would be to design model whey protein $/ \mathrm{K}$ casein complexes having one targeted physico-chemical property largely modulated, then to introduce them to whey protein-free milk as a means to promote (or knock out) one specific type of interaction during acidification. If this modulation induces a correlated change in the acid gelation behaviour of the milk, the corresponding interaction may then be identified as important to the formation of the acid milk gel. Because they are separated from the casein micelles and because the acid gelation functionality of the heat-induced whey protein/K-casein complexes does not seem to depend on their soluble or micelle-bound location (Donato et al. 2007a; Guyomarc'h et al. 2009a), the soluble complexes seem good candidates to be used as vectors to modulate interactions in milk.

In this perspective, the present review will first overview, out of recent research (Alting et al. 2002, 2003, 2004; Donato et al. 2007a; Guyomarc'h et al. 2009a, 2007), the different physico-chemical properties of the soluble whey protein/Kcasein complexes that may be important to either the onset of acid gelation (in a first section) or the strengthening of the acid gel network (in a second section). Then, the various physical, biological or chemical means that could help control each listed property in either section will be reviewed. The review therefore aims at providing a set of methods that may help modify whey protein/K-casein soluble complexes produced in model systems (Donato et al. 2007b; Guyomarc'h et al. 2009b) or isolated from milk. Should this approach be too restrictive, the review also provides methods to generate derivative whey protein, food protein or food protein $/ \mathrm{K}$-casein heat-induced complexes through introducing controlled changes, e.g. in the protein composition of the heat-induced whey protein/K-casein complexes. In order to open a large range of opportunities for future investigation, the choice was made to seek these methods not only in studies on milk, but also in studies on milk protein fractions, on isolated milk proteins or on non-dairy globular food proteins. In the latter cases, the applicability of the methods to the whey protein $/ \mathrm{K}$-casein complexes or their derivatives is yet to be evidenced. On the other hand, these literature areas bring new resources to import methods from.

In heated milk, it is well-known that the heat-induced whey protein/K-casein complexes are parted between the serum and the colloidal phases of milk (Anema 2007; Guyomarc'h et al. 2003b; Vasbinder and de Kruif 2003). Because of the 
chosen strategy to introduce modified soluble whey protein/K-casein complexes as vectors to modulate interactions in milk, the means to control the serum/micelle partition of the heat-induced complexes in milk are out of the scope of the present review. Information can be found in Donato and Guyomarc'h (2009). For the same reason, the heat-induced changes in the composition and structure of the casein micelles, as well as their possible consequences on acid gelation, are excluded.

\section{Properties of the heat-induced whey protein/K-casein complexes that may affect the onset of acid gelation in milk}

2.1 Possible roles of the heat-induced whey protein/K-casein complexes on the acid destabilisation of milk

In the search for an appropriate model to describe their structure and account for their behaviour in a number of processes, the stability of casein micelles in skim milk has long been thoroughly discussed (Dalgleish 1998; de Kruif 1998; Holt and Horne 1996; Horne 1998; Tuinier and de Kruif 2002; Walstra 1990). In essence, destabilisation of the casein micelle may occur through their disintegration or aggregation. On acidification to $\mathrm{pH}$ values $\sim 5.2$, dissolution of the colloidal calcium phosphate and the increase in hydration of the casein molecules essentially account for loosening of the casein micelles' structure (Banon and Hardy 1992; Walstra 1990). Collapse of the outer $\mathrm{K}$-casein brush as $\mathrm{pH}$ decreases to $\sim 5.0$, neutralisation of the electrostatic repulsion between negatively charged casein particles as $\mathrm{pH}$ approaches $\mathrm{p} I \sim 4.8$ and the occurrence of dipole-dipole or hydrophobic attractions further yield to gelation (Banon and Hardy 1992; Tuinier and de Kruif 2002; van Vliet et al. 1989). As the casein micelles loosen and rearrange throughout acidification (Gastaldi et al. 1996), the exact nature of the casein "micelles" that eventually form the particulate gel is not known, which sensibly challenges modelling (Horne 2003). In heated milk, the presence of heat-induced whey protein/K-casein complexes increases the $\mathrm{pH}$ at which gelation onsets from $\mathrm{pH} \sim 4.8$ to 5.4 (Graveland-Bikker and Anema 2003; Guyomarc'h et al. 2003a; Heertje et al. 1985; Lucey et al. 1997a). It is hypothesized that the complexes modify the surface properties of casein micelles as to increase net colloidal attraction, hence decreasing the threshold for acid destabilisation (Donato and Guyomarc'h 2009).

Among the forces that balance interaction between the casein micelles during acidification of the milk, electrostatic repulsion and the $\mathrm{p} I$ value are clearly important (Tuinier and de Kruif 2002). Since the $\mathrm{p} I$ can determine the $\mathrm{pH}$ of gelation of heatinduced whey protein complexes (Alting et al. 2002), the $\mathrm{pH}$ of gelation of milk may similarly depend on the $\mathrm{p} I$ of the heat-induced whey protein/K-casein complexes. Attractive hydrophobic interaction has also been emphasized through the effect of temperature (Banon and Hardy 1992). As they carry significant surface hydrophobicity, it was suggested that the heat-induced whey protein/K-casein complexes also promoted destabilisation through increasing attraction (Famelart et al. 2004; Guyomarc'h et al. 2007; Jean et al. 2006). Calculation showed that long-range van der Waals attraction also counterbalances electrostatic repulsion and may account for aggregation below pH 5 (Tuinier and de Kruif 2002). Despite the above literature, 
there is to date no general picture of how the heat-induced whey protein/K-casein complexes contribute to increasing the $\mathrm{pH}$ at which acid gelation starts in heated milk, i.e. through which of the above-listed interaction(s) they favour precipitation of the casein micelles. It is however expected that:

- They easily interact with the surface of the casein micelles.

- They reinforce hydrophobic attraction and/or reduce electrostatic repulsion.

\subsection{Possible methods to modify the surface charge and apparent $\mathrm{p} I$} of the heat-induced whey protein/K-casein complexes

In milk ultrafiltration permeate, the soluble whey protein/K-casein complexes isolated from heated skim milk have a $\mathrm{p} I$ of $\sim 4.5$, a net charge of $-18 \mathrm{mV}$ at $\mathrm{pH} 6.7$ and they start precipitating at $\mathrm{pH} 5.3-5.5$ on acidification (Guyomarc'h et al. 2007; Jean et al. 2006). A first, natural approach to help modify the net charge of the heat-induced whey protein/K-casein complexes could be to use biodiversity. The major whey protein $\beta$-LG comes in a range of up to 11 genetic variants, of which the $\mathrm{A}\left(\mathrm{ASP}_{64}, \mathrm{VAL}_{118}\right)$ and $\mathrm{B}$ forms $\left(\mathrm{GLY}_{64}, \mathrm{ALA}_{118}\right)$ are most represented (Farrell et al. 2004). Although the negative net charge of $\beta-L G A$ is known to be higher than that of $\beta-\mathrm{LG} \mathrm{B}$, it only slightly affected the $\mathrm{pH}$ of acid gelation of an $\mathrm{AB}$ skim milk to which up to $1.4 \mathrm{~g} \cdot \mathrm{kg}^{-1}$ of either variant had been added prior to heat treatment (Bikker et al. 2000). In common bovine breeds, K-casein also comes in two major variants, $\mathrm{A}\left(\mathrm{THR}_{136}, \mathrm{ASP}_{148}\right)$ and $\mathrm{B}\left(\mathrm{ILE}_{136}, \mathrm{ALA}_{148}\right)$. On the basis of their sequence only, $\mathrm{K}$-casein is weakly negatively charged and variant B slightly more than A (Cayot and Lorient 1998). However, the net charge of K-casein is further increased by the large range of phosphorylated and glycosylated forms (Vreeman et al. 1986), K-casein B being also more glycosylated than A (Robitaille et al. 1991). However, despite cumulated sources of charge on variant B, and despite some variant-specific changes in the heat-induced interaction of $\mathrm{K}$-casein with $\beta$-LG (Allmere et al. 1998b; Robitaille and Ayers 1995), no or barely significant changes could be reported in the acid gelation kinetics of preheated individual milk genotypes (Allmere et al. 1998a). These results probably rule out the biodiversity of $\beta$-LG and $\mathrm{k}$-casein as a means to modulate the net charge of the heat-induced whey protein/K-casein complexes across a sufficiently large range.

It may be otherwise possible to modulate the net charge and/or the apparent $\mathrm{p} I$ of heat-induced whey protein/K-casein complexes by transferring methods used outside the conditions of milk. Bovetto et al. (2007) and Schmitt et al. (2009) have for instance delivered a method to produce heat-induced nanoparticles of $\beta$-LG having similar hydrodynamic diameter (typically 160-230 nm) but opposite net charges of $+25-30$ or $-30-40 \mathrm{mV}$, using heat treatment of pure $\beta-\mathrm{LG}$ at $\mathrm{pH} 4.6$ or 5.8 , respectively, in deionised water. Since the resulting complexes are partially built on disulphide covalent bonds, some conformational stability, hence residual charge difference, may be expected if the $\beta$-LG complexes are later transferred to a nearneutral medium like milk.

Another approach to try to modulate the overall charge and apparent $\mathrm{p} I$ of heatinduced whey protein/K-casein complexes could be to involve cysteine-containing exogenous globular protein into the complexes, with special interest in proteins 
having $\mathrm{p} I$ values away from those of the casein micelles and the heat-induced whey protein/K-casein complexes, i.e. 4.2-4.5 (Guyomarc'h et al. 2007). Prior to heat treatment, skim milk could for instance be reinforced in basic proteins like lactoferrin ( $\mathrm{p} I \sim 8.7$ ) or egg lysozyme $(\mathrm{p} I \sim 11)$ which are both able to aggregate with at least $\alpha$-lactalbumin ( $\alpha$-LA; Nigen et al. 2009; Takase 1998). Soy glycinin ( $\mathrm{p} I \sim 6.4$ ) and conglycinin ( $\mathrm{p} I \sim 4.9$ ) could also be helpful to modulate the $\mathrm{p} I$ of heatinduced globular protein/K-casein complexes. Roesch and Corredig $(2006,2005)$ and Roesch et al. (2004) have for instance shown that the co-heating of pure soy and whey protein isolates in $0.1 \mathrm{~mol} . \mathrm{L}^{-1} \mathrm{NaCl}$ at $\mathrm{pH} 7$, of soy protein isolate and skim milk, or of soy protein isolate, whey proteins and casein micelles in milk ultrafiltration permeate, produced heat-induced soy/whey or soy/whey/k-casein soluble complexes that yielded acid gelation profiles with an increased gelation $\mathrm{pH}$ value of $\sim 6.0$. Egg ovalbumin ( $I \sim 4.8$ ) was also effectively co-heated with whey protein-depleted skim milk to produce complexes that increased the $\mathrm{pH}$ of acid gelation of the modified milk (Famelart et al. 2003, 2004). However, since $\beta$-LG has a higher $\mathrm{p} I(\sim 5.3)$ than ovalbumin, charge was obviously not the only driving factor to earlier destabilisation of the milk.

Although it is somewhat less acceptable in food processing, chemical or enzymatic modification of milk proteins may also be considered in order to modify the surface charge of the heat-induced whey protein/K-casein complexes. Alting et al. (2002) for instance used succinylation of free amino groups to increase the net charge and decrease the $\mathrm{p} I$ of heat-induced complexes of either pure $\beta$-LG or WPI produced in water at $\mathrm{pH}$ 7.2. They reported a remarkable correlation between the apparent $\mathrm{p} I$ of the grafted complexes and their $\mathrm{pH}$ of gelation on acidification. They also indicated that it was possible to increase the $\mathrm{p} I$, hence the gelation $\mathrm{pH}$ of heatinduced $\beta$-LG or whey protein isolate (WPI) complexes through methylation of the carboxylic groups. However, the results were not shown. Sitohy et al. (1995) also succeeded in decreasing the $\mathrm{p} I$ of $\beta$-LG through chemical phosphorylation mediated by aliphatic amines.

Non-specific fixation of charged ligands using, e.g. anionic surfactants like sodium dodecyl sulphate (SDS) onto the hydrophobic patches of the heat-induced whey protein/K-casein complexes may also be attempted to help increase their net charge. Risso et al. (2000) for instance reported that the net charge of heated casein micelles resuspended in aqueous Tris- $\mathrm{HCl}-\mathrm{CaCl}_{2}$ buffer at $\mathrm{pH} 6.4$ could be increased by the binding of anionic fluorescent probes. Jung et al. (2008) further reported that the double-coating of $\beta$-LG heat-induced complexes by SDS in water through successive electrostatic and hydrophobic interactions could eventually reverse their net charge. However, application of the method to whey protein/Kcasein complexes may have consequences on their structure, especially in the case of surfactants, because they are partially built on hydrophobic interactions (Jean et al. 2006). When the complexes are introduced into milk, the ligands may also diffuse and cross-bind to casein micelles, thus rendering the control of colloidal interactions difficult.

Food-grade alternatives exist that may prove less flexible. A first one may be to attach sugars to the $\varepsilon$-amines of the whey protein/K-casein complexes through Maillard reaction. Indeed, one can expect to decrease the $\mathrm{p} I$ of the complexes through glycation of the amines. Using this approach, the $\mathrm{pH}$ of minimum 
solubility or of isoelectric focusing of pure $\beta$-LG can for instance be shifted from $\sim 5.0$ to $\sim 4.0$ (Chevalier et al. 2001; Corzo-Martinez et al. 2008). It is also conceivable to reduce the $\mathrm{p} I$ of $\beta$-LG through Maillard conjugation with acidic oligosaccharides (Hattori et al. 2004). To the author's knowledge, no data is yet available on the use of the Maillard reaction to modify the $\mathrm{p} I$ of heat-induced whey protein or whey protein/K-casein complexes. Morgan et al. (1999) albeit showed that heat-induced glycation and polymerization of $\beta-\mathrm{LG}$ could occur concomitantly in solution at $60{ }^{\circ} \mathrm{C}$ and yield heat-induced complexes that partially remained soluble at $\mathrm{pH} 4.6$.

Second, enzymatic cleavage of the K-casein's negatively charged glycosyl group using neuraminidase, or of the caseinomacropeptide using chymosin, could also be attempted to modify the net charge of heat-induced whey protein/K-casein complexes. The method has been shown to increase the $\mathrm{pH}$ of acid gelation of the casein micelles in milk (Cases et al. 2003; Gastaldi et al. 1996; Li and Dalgleish 2006; Niki et al. 2003). Renan et al. (2007), Anema et al. (2007) and Mollé et al. (2006) showed that $\mathrm{K}$-casein as involved in the heat-induced whey protein/K-casein complexes of milk could also be cleaved by chymosin. Reduction of the electronegativity of the complexes may then account for the increase in the $\mathrm{pH}$ of gelation of heated skim milk after moderate renneting (Guyomarc'h et al. 2007; Li and Dalgleish 2006). However, to the authors' knowledge, no demonstration has been given that the $\mathrm{p} I$ of the heat-induced whey protein/K-casein complexes actually increased with renneting nor that the $\mathrm{pH}$ of gelation of milk would equally increase if only the heat-induced complexes were renneted.

A wide literature otherwise exists on performing chemical grafting, enzymatic cleavage or ligand addition onto the constitutive protein (generally $\beta$-LG or other globular food model protein) prior to their heat-induced aggregation. But, it is then quite likely to affect the denaturation and aggregation processes themselves and hence, to also modify other properties than the charge of the complexes (e.g. Mine (1996), Broersen et al. (2006, 2007) on ovalbumin, Giroux and Britten (2004), Chakraborty et al. (2009), Bouhallab et al. (1999), Chobert et al. (2006) on whey proteins or glycated $\beta$-LG and Murphy and Howell (1990)). Modifying the $\mathrm{p} I$ of the constituted complex, using the above mentioned techniques, therefore seems a preferred approach to evaluate the role of electrostatic interactions in the acid gelation of milk.

In conclusion, numerous methods exist that may be applied to the heat-induced whey protein/K-casein complexes in order to modulate their electrostatic properties. In essence, the complexes preferably precipitate across a $\mathrm{pH}$ range that is centred at their $\mathrm{p} I$ value but also depends on how their absolute net charge increases as the $\mathrm{pH}$ is shifted away from the $\mathrm{p} I$ (charge vs $\mathrm{pH}$ curve). Therefore, in order to increase the $\mathrm{pH}$ at which the heat-induced soluble whey protein/K-casein complexes should precipitate in milk conditions, one can either aim at increasing their $\mathrm{p} I$ or at decreasing their net negative charge throughout the $\mathrm{pH}$ range between the $\mathrm{p} I$ and the initial $\mathrm{pH}$ of milk, $\mathrm{pH}$ 6.7. However, it is very important to keep both goals in mind and to always consider the charge vs $\mathrm{pH}$ curve when modulating the electrostatic properties of the heat-induced whey protein/K-casein complexes. This should avoid situations where the successful increase of their $\mathrm{p} I$, for instance, is counteracted by the simultaneous increase of their absolute net charge, hence their electrostatic 
repulsion, too close to the $\mathrm{p} I$. The charge vs $\mathrm{pH}$ curve also closely depends on the ionic composition of the medium, since, e.g. calcium ions may screen the exposed charges on the whey protein/K-casein complexes throughout the acidic $\mathrm{pH}$ range. As we intend to introduce the modified heat-induced whey protein/K-casein soluble complexes to a whey protein-free skim milk, the ionic background at the time of measurement will remain constant. However, this effect of the surrounding ions should be kept in mind if the charge and $\mathrm{p} I$ of the complexes are to be compared in different mediums.

\subsection{Possible methods to modify the surface hydrophobicity of the heat-induced} whey protein/K-casein complexes

As for charge, the protein's genetic variants are a natural source of control over the surface hydrophobicity of the whey protein/ $/$-casein complexes. Typically, $\beta$-LG B is slightly more hydrophobic than A (Allmere et al. 1997) and so is K-casein B as compared to A (Kyte and Doolittle 1982). However, as already mentioned, the natural biodiversity of $\beta$-LG or $\mathrm{K}$-casein fails to induce sensible changes neither in their heat-induced complex formation nor in the $\mathrm{pH}$ of acid gelation of the heated milk. Most likely, changes in hydrophobicity across variants do not range widely enough to be efficient.

Because $\alpha$-LA has a significantly lower theoretical hydrophobicity than $\beta$-LG or $\mathrm{K}$-casein (Cayot and Lorient 1998), it may also be possible to modulate the surface hydrophobicity of the soluble whey protein/K-casein heat-induced complexes through modulating the protein composition of milk or model systems prior to heating. Graveland-Bikker and Anema (2003) added various amounts of $\alpha$-LA and $\beta-L G$ to whey protein-free skim milk, then heated the mixture and observed that the gelation $\mathrm{pH}$ was increased to a larger extent in the presence of $\beta$-LG than $\alpha$-LA. However, the results were discussed in terms of increased number of free thiol groups available for thiol/disulphide polymerisation, rather than in terms of increased surface hydrophobicity of the complexes, when more $\beta$-LG was present.

Alternatively, enzymatic or chemical tools have to be considered. Deglycosylation (Cases et al. 2003) or renneting (Gastaldi et al. 1996; Li and Dalgleish 2006; Niki et al. 2003) has already been performed on the K-casein in casein micelles or whey protein/K-casein complexes. The processes are likely to readily expose hydrophobic regions of the $\mathrm{k}$-casein as they cleave hydrophilic moieties of the protein. However, if hydrophobicity of the casein micelle indeed increases when they are renneted (Peri et al. 1990), this has not yet been demonstrated when renneting the heat-induced whey protein/K-casein complexes.

Because they catalyze polymerisation reactions that involve charged side groups, transglutaminase or redox enzymes laccase, lactoperoxidase or glucose oxidase also increase the surface hydrophobicity of whey proteins or caseins (Hiller and Lorenzen 2008). However, oxidoreductases also promote oxidation of thiol groups into intermolecular disulphide bonds (Hiller and Lorenzen 2008), which could result in changes in formation of the whey protein/K-casein heat-induced complexes. Gerbanowski et al. (1999) acylated or sulfonylated the lysine's $\varepsilon$-amines of BSA and reported an increase in its surface hydrophobicity as a result of chemical grafting. However, only sulfamidation maintained the secondary structure of the 
protein. In a different approach, Risso et al. (2000) bound non-anionic hydrophobic Nile Red probes onto casein micelles and reported earlier and faster rennet aggregation. The authors further argued that Nile Red could increase surface hydrophobicity of the casein micelles, without changing either their net charge or their fractal dimension. As Nile Red can bind at least to $\beta$-LG and $\kappa$-casein (Sackett and Wolff 1987), it seems an interesting approach to explore the role of surface hydrophobicity of whey protein/K-casein soluble complexes in acid gelation, independently of other properties like charge.

Eventually, it may be possible to induce changes in the hydrophobicity of heatinduced whey protein/K-casein complexes by controlling the temperature of heat treatment. Clearly, unfolding of the whey proteins on denaturation increases their exposed hydrophobicity (Relkin 1998). This reaction most likely accounts for the high surface hydrophobicity of the heat-induced whey protein complexes (Guyomarc'h et al. 2007; Jean et al. 2006; Relkin 1998), albeit Gatti et al. (1995) or Carbonaro et al. (1996) have pointed out that aggregation also engages hydrophobic sites and somewhat limits the gain. Since the work by Dannenberg and Kessler (1988b, c), convergent studies have established that the two-step denaturation/aggregation reaction that yield the whey protein/K-casein complexes obeys different kinetics below and above $\sim 90{ }^{\circ} \mathrm{C}$ (Anema and McKenna 1996; de Jong et al. 1996; Verheul et al. 1998). Although the common interpretation is that either step is limiting below or above $90{ }^{\circ} \mathrm{C}$, de Jong et al.'s calculations (1996) alternatively suggested that unfolding is incomplete at temperatures above $90{ }^{\circ} \mathrm{C}$, hence the lower overall activation energy for the reaction. Furthermore, the aggregation step involves more $\alpha$-LA at temperatures above $80{ }^{\circ} \mathrm{C}$ (Mottar et al. 1989; Oldfield et al. 1998a), which is believed to adversely affect the surface hydrophobicity of the heat-induced complexes at UHT temperatures (Mottar et al. 1989). In his review, de Wit (2009) also explains that at temperatures above $90{ }^{\circ} \mathrm{C}$, hydrophobic interactions are prevented due to rearrangement of the water molecules around exposed non-polar regions of the whey proteins. Also, heat-resistant $\beta$-sheet and $\beta$-strand structures, which confer high local hydrophobicity to the $\beta$-LG, eventually unfold at $>125^{\circ} \mathrm{C}$. The use of high temperature treatments to produce the heat-induced whey protein/K-casein complexes in milk or model systems may therefore decrease their surface hydrophobicity.

Eventually, Kella et al. (1989) increased the surface hydrophobicity of whey proteins using sulfitolysis of the internal disulphide bonds to loosen their structure, using food-grade reagents. However, its interest as to increase hydrophobicity on already denatured, disulphide-linked whey protein/K-casein complexes is yet to be established.

In conclusion, however, one has to bear in mind that manipulating the hydrophobicity of the whey protein/K-casein complexes without changing their absolute net charge is likely to be a challenge. This challenge is important so that the role of hydrophobic interactions can be discriminated from that of electrostatic ones when using modified heat-induced soluble whey protein/K-casein complexes to identify the type of interactions that drives the acid gelation of heated milk. In this regard, the method used by Risso et al. (2000) to modify the surface hydrophobicity of casein micelles independently of other properties may prove particularly interesting. 
2.4 Possible importance of the $\mathrm{k}$-casein in the acid gelation functionality of the heat-induced whey protein/K-casein complexes

Since the addition of heat-denatured whey protein ingredients is effective in increasing the $\mathrm{pH}$ of gelation of milk (O'Kennedy and Kelly 2000; Schorsch et al. 2001; Vasbinder et al. 2004), one could question the importance of the $\mathrm{K}$-casein in determining the functionality of the heat-induced whey protein $/ \mathrm{K}$-casein complexes. In their study, O'Kennedy and Kelly (2000) pointed out the importance of early interactions between the heat-induced whey protein complexes and casein micelles on gelation $\mathrm{pH}$, the earliest being obtained through co-heating of the two fractions. In milk conditions, this binding occurs naturally through formation of heat-induced whey protein/K-casein complexes on the surface of the casein micelles (Dalgleish 1990; Jang and Swaisgood 1990). Although some heat-induced whey protein/Kcasein complexes are also found in the serum phase of heated milk (Creamer et al. 1978; Guyomarc'h et al. 2003b; Noh et al. 1989; Smits and van Brouwershaven 1980), they are thought to bind to the surface of casein micelles early on acidification, i.e. prior to destabilisation of the milk (Alexander and Dalgleish 2005; Donato et al. 2007a, b; Guyomarc'h et al. 2009a). Various authors have further reported that soluble whey protein/K-casein complexes having a higher proportion of $\mathrm{K}$-casein were produced on heat-treating milk at slightly increased $\mathrm{pH}$ values from 6.5 up to 8.1 (Anema 2007; Donato and Dalgleish 2006; Menard et al. 2005; Renan et al. 2006). These milks also exhibited an increased $\mathrm{pH}$ of acid gelation, typically $+0.2-0.4 \mathrm{pH}$ unit (Anema et al. 2004; Vasbinder and de Kruif 2003). Among other causes and according to our interpretation, it may be that a higher content in $\mathrm{K}$-casein renders the soluble complexes more prone to interact with the casein micelles, where $\mathrm{K}$-casein initially belongs, thus accelerating gelation. This could simply happen because the soluble whey protein/K-casein complexes are also smaller and more numerous as they contain more K-casein (Donato and Guyomarc'h 2009), hence more likely to encounter casein micelles through diffusion. Alternatively, the involvement of $\mathrm{K}$-casein into the heat-induced whey protein/K-casein complexes may accelerate acid gelation because formation of the soluble complexes has depleted the casein micelle of its $\mathrm{K}$-casein and/or because the micelle-bound complexes hinder the stabilising action of the $\mathrm{K}$-casein. In conclusion, the role of the presence of $\mathrm{K}$-casein in the heat-induced complexes on the acid gelation of milk still needs to be confirmed. This role could either occur through the possible ability of the whey protein/K-casein complexes to build facilitated interactions with casein particles in milk during the acidification or thought the removal of $\mathrm{k}$-casein from the casein micelle. The latter case however relates to the partition of the heat-induced whey protein/K-casein complexes in milk (reviewed by Donato and Guyomarc'h (2009)), rather than to the controlled modification of soluble whey protein/K-casein complexes prior to their introduction to milk, as presently reviewed.

In conclusion, the role of the presence of $\mathrm{K}$-casein in the whey protein $/ \mathrm{K}$-casein complexes formed in heated milk still needs to be evaluated. Following the approach proposed in this review, it could be interesting to modulate the content of the complexes in $\mathrm{K}$-casein, in order to test whether the presence of this casein influences the acid gelation of milk through facilitated interactions with the casein micelles during the acidification. 


\section{Properties of the heat-induced whey protein/K-casein complexes that may affect the strength of acid milk gels}

\subsection{Structure and mechanical properties of acid dairy gels}

In most studies, interactions that build the acid milk gel are investigated using large or low amplitude rheology and confocal or electron microscopy. These tools generally provide an overall view of the strength, lifetime and isotropy of the constitutive interactions, of which it is somewhat difficult to discriminate the respective contributions of the casein micelles and of the heat-induced whey protein/ $\mathrm{K}$-casein complexes. On the basis of our current knowledge of the type of interactions that take part in acid milk gels, one approach could be to modify the heat-induced whey protein/K-casein complexes as to knock out or enhance their ability to engage a selected type of interaction. If a relationship was found between these variations of the targeted property of the complexes and the mechanical and structural properties of the resulting acid gel, it would indicate the relevance of the selected interaction in affecting the course of the acid gelation of the milk.

In their study of acid milk gels prepared through acidification at $4{ }^{\circ} \mathrm{C}$ then warmup, Roefs and van Vliet (1990) and van Vliet et al. (1989) indicated that acid milk gels are essentially structured by electrostatic dipole attraction and by hydrophobic interactions. The fact that skim milk does not gel on acidification at $4{ }^{\circ} \mathrm{C}$ but gels at higher incubation temperatures shows the implication of hydrophobic interactions in the network (Roefs et al. 1990). This was further demonstrated by Lefebvre-Cases et al. (1998) or Hinrichs and Keim (2007) who successfully dissociated acid milk gels in SDS. Disulphide covalent bonds have also been evidenced to sustain the acid gels' network (Hinrichs and Keim 2007) as a result of the formation of heat-induced whey protein/K-casein complexes on heating the milk. Covalent bonds are thought to account for the increased elastic modulus $G^{\prime}$ and lower $\tan \delta$ of acid gels made with heated milk (Guyomarc'h et al. 2003a). Vasbinder et al. (2004) further showed that thiol/disulphide exchanges occur throughout acidification of milk where heatinduced complexes are present and evidenced that disulphide bonds contribute to the increase in G' on gel formation. To a minor extent, hydrogen bonds have also been suspected to play a role in the gel network (Lefebvre-Cases et al. 1998).

Comparison between unheated milk and sodium caseinate showed that ionic calcium binding does not contribute to the acid milk gel (Lucey et al. 1997b, c). However, heat-aggregated whey proteins can bind calcium (Halbert et al. 2000; Morr 1985; O'Connell and Fox 2001; Simons et al. 2002), but this has yet to be demonstrated in whey protein/K-casein complexes. It is possible that bound calcium increases the rigidity of the heat-induced whey protein complexes and has consequences on the mechanical properties of the resulting acid gels. But this also has not yet been evaluated. Famelart et al. (2009) suggested that calcium ions as bound to phosphoserine residues in the casein micelles may help strengthen the final acid milk gel. Since the K-casein molecule has one phosphoserine, this finding may be relevant to the whey protein/K-casein complexes of heated milk.

Another important feature of dairy gels is their ability to hold water. The presence of heat-aggregated whey proteins clearly decreases syneresis and drainage in acid dairy gels (Guyomarc'h 2006; Vardhanabhuti et al. 2001). The causes are that, first, 
denaturation and formation of the heat-induced complexes create new porous structures into which water influxes and immobilises (Denisov et al. 1999; Hinrichs et al. 2004). At the molecular level, unfolding of some secondary structures in the whey proteins induces rearrangement of the hydration water around non-polar groups. Competition of the water molecules for hydrogen interactions within intramolecular $\beta$-sheets and $\alpha$-helices increases, thus increasing bound water and hydration (de Wit 2009; Denisov et al. 1999). At a larger scale, the heat-induced whey protein/K-casein complexes finally affect microstructure of the acid gels. Their presence clearly promotes the formation of protein strands between the casein clusters, thus enhancing cohesiveness, connectivity and homogenous porosity, which in turn affect firmness and permeability of the gel (Lucey et al. 1999, 1998b; Vasbinder et al. 2004). Furthermore, solid, long-time relaxing bonds like those found in the complexes may help prevent intra-particle rearrangement and syneresis, in continuation of the reasoning by van Vliet et al. (1991) or van Vliet and Walstra (1994).

In conclusion, in order to affect the final gel strength of acid skim milk gels, it is hypothesized that the heat-induced whey protein/K-casein complexes:

- Engage the type of interactions that build the gel network (in particular, disulphide or other covalent bonds, hydrophobic attraction, electrostatic attraction)

- Sustain the gel's structure by enhancing connectivity between the casein clusters

- Immobilise and help immobilise water through controlling porosity of the gel

3.2 Possible methods to modify the protein interactions that build the heat-induced whey protein/K-casein complexes

By varying the conditions of heat treatment, it is possible to modulate the nature of interactions that build the whey protein/K-casein complexes. For instance, increasing the $\mathrm{pH}$ of heat treatment of WPI from 6.0 to 8.0 (i.e. closer to $\mathrm{pK}_{\mathrm{SH} / \mathrm{S}_{-}} \sim 9$ ) has been shown to increase the proportion of intermolecular disulphide bonds in the complexes (Hoffmann and van Mil 1999). In skim milk, an increased proportion of covalent disulphide bonds in the heat-induced whey protein $/ \mathrm{K}$-casein complexes produced at $\mathrm{pH}$ up to 7.3 (Donato and Dalgleish 2006) could partly account for the higher elastic modulus of the resulting acid gels (Anema et al. 2004). On the contrary, blocking the free thiol groups of WPI with N-ethyl-maleimide (NEM) prior to heating yields complexes that fully dissociate in presence of SDS (Hoffmann and van Mil 1997). Absence of disulphide bonds within the heat-induced complexes may then account for the low final G' value of skim milk that was heat-treated in presence of NEM, then acidified (Lucey et al. 1998a). Vasbinder et al. (2003) further showed that thiol/disulphide exchanges continue throughout acidification and significantly contribute to the final gel strength.

Alternatively to variation of the $\mathrm{pH}$ of heat treatment, one can modulate thiol/ disulphide exchanges in the heat-induced complexes through varying the redox conditions. Reduction of part of the disulphide bonds can be performed using chemical agents like $\beta$-mercaptoethanol (Goddard 1996; Surel and Famelart 2003) or food-grade alternatives (Kella et al. 1989). By applying electroreduction on whey 
protein ingredients, Bazinet et al. (1997) could modulate thiol/disulphide-mediated aggregation and reported correlated changes in thermal gelation behaviour. Oxidation to form disulphide bonds can be performed using $\mathrm{H}_{2} \mathrm{O}_{2}$ (Nabi et al. 2000) by bubbling air or oxygen (Martin et al. 2009; Wanatabe and Klostermeyer 1976) and can be mediated using enzymes to yield disulphide polymers of the whey proteins (Faergemand et al. 1998).

The addition of extra thiol groups to $\beta-\mathrm{LG}$ either by chemical thiolation (Kim et al. 1990) or genetic engineering (Lee et al. 1993) dramatically increases their ability to polymerise through thiol/disulphide exchange or oxidation. Conversely, it is also possible to generate a thiol-free mutant of bovine $\beta$-LG (Jayat et al. 2004) or to use thiol-free porcine $\beta$-LG (Gallagher and Mulvihill 1997) in order to reduce disulphide polymerisation. Lee et al. (1994) reported significant changes in whey syneresis when using genetically modified milk to make yoghurt.

Providing that one of them (generally $\beta-\mathrm{LG}$ or BSA) contains one free thiol group (Calvo et al. 1993; Matsudomi et al. 1993), it is also possible to coaggregate globular proteins with varying amounts of cysteines and cystines as a mean to affect the acid gelation of milk through changes in the thiol/disulphide ratio of the heat-induced complexes. This could be done either by addition of exogenous globular protein to dairy systems (Famelart et al. 2004; Roesch and Corredig 2006) or by affecting the natural composition of whey proteins in milk (Graveland-Bikker and Anema 2003). Kehoe et al. (2007) reported different acid gelation properties of $\mathrm{BSA} / \beta-\mathrm{LG}$ heat-induced complexes depending on their ratio and discussed these results in terms of different ability to thiol/disulphide exchanges of the respective proteins. All these approaches indicate that increasing the number of cysteines, rather than cystines, in the reactant proteins enhances acid gel strength.

Interestingly, $\mathrm{K}$-casein that is specific to the formation of heat-induced whey protein/K-casein complexes in the milk exhibits enhanced aggregative behaviour when in reduced form (Thorn et al. 2005). Stevenson et al. (1996) demonstrated that the thiolation of caseins other than $\kappa$ could help involve, e.g. $\beta$-casein into heatinduced covalent whey protein complexes. A natural alternative could be to exploit biodiversity in the cysteine content of caseins (Bouguyon et al. 2006).

Despite the high intrinsic energy of covalent disulphide bonds relative to that of low energy interactions (Walstra 2003a, b), model thiol/disulphide interchange only requires $60-70 \mathrm{~kJ}^{-\mathrm{mol}^{-1}}$ to occur in water (Fernandes and Ramos 2004). This is in agreement with the estimate of the activation energy of aggregation of the unfolded $\beta$-LG in heated milk (Ea $\sim 55 \mathrm{~kJ} . \mathrm{mol}^{-1}$, de Jong (1996)). Such figures are common for bimolecular/chemical reactions where the breaking and formation of bonds are usually synchronous, so that the overall energy demand is low (van Boekel and Walstra 1995; Walstra 2003b). This suggests that thiol/disulphide exchanges might readily occur, as soon as the reactive sites are in presence. Therefore, another way to act on the thiol/disulphide exchanges in the heat-induced whey protein $/ \mathrm{K}$-casein complexes is to physically control contact between the major reactants, namely, the unfolded whey proteins.

Due to the breaking of a large number of intramolecular hydrogen bonds on unfolding, denaturation of the whey protein results in a large increase in conformational entropy and makes the unfolded protein a thermodynamically 
unfavourable structure (van Boekel and Walstra 1995; Walstra 2003b). Once the protein is unfolded, water molecules organise in the vicinity of the exposed hydrophobic sites as to "exclude" or "cavitate" them from solvent. Intermolecular hydrophobic interactions therefore readily stabilise the denatured proteins. Within such hydrophobic pockets, Fernandes and Ramos (2004) calculated that thiol/ disulphide exchanges are dramatically accelerated. Promoting hydrophobic interactions between the protein therefore enhances disulphide polymerisation, in agreement with Oldfield et al. (1998b). Similarly, O'Kennedy and Mounsey (2009) and Mounsey and O'Kennedy (2007) insisted that aggregation of heatdenatured $\beta-\mathrm{LG}$ is largely initiated by non-specific attractive electrostatic and hydrophobic interactions, as favoured at $\mathrm{pH}$ close to $\mathrm{p} I$ and/or increased ionic strength. When working on humid dairy powders of WPI, Zhou et al. (2008) observed that the whey protein molecules can undergo partial unfolding and extensive thiol/disulphide exchanges at $35{ }^{\circ} \mathrm{C}$ providing that the high protein concentration allows close contacts between proteins. In conclusion, in order to control the thiol/disulphide balance in the heat-induced whey protein $/ \mathrm{K}$-casein complexes one could aim at (1) increasing the number of thiols and thiolates (Fernandes and Ramos 2004) and (2) favouring close contact between proteins.

Intermolecular interactions other than disulphide may also be promoted in the heat-induced complexes. Attractive electrostatic interactions are somewhat significant in protein binding (Xu et al. 1997) and can be promoted if introducing proteins of opposite net charge at the $\mathrm{pH}$ of heating. Nigen et al. $(2009,2007)$ for instance generated electrostatically driven nano-coacervates of apo- $\alpha$-LA and lysozyme at $\mathrm{pH} 7.5$ and $45{ }^{\circ} \mathrm{C}$. By comparing $\beta$-LG molecules with chemically varied affinities for calcium ions, Simons et al. (2002) estimated unlikely that calcium ions formed intermolecular bridges in the heat-induced complexes. Therefore, ionic calcium bridges are probably not a lever for controlled changes in the building interactions. Thiol-blocked $\beta$-LG has been shown to form noncovalent high molecular mass aggregates on heating model solutions at neutral $\mathrm{pH}$ and low ionic strength (Hoffmann and van Mil 1997; Mounsey and O'Kennedy 2007), and Mounsey and O'Kennedy (2007) observed that these aggregates nonetheless yielded as high elastic moduli values on acid gelation as did the control $\beta$-LG covalent complexes.

Eventually, the use of polymerisation enzymes like glutaminase may help stiffen the heat-induced whey protein/K-casein complexes, in the same way it has been shown to increase gel strength in acid skim milk or casein gels (Bonisch et al. 2007; Lorenzen et al. 2002). The studies by Gauche et al. (2009) and Bönisch et al. (2007) suggested that the whey proteins cross-linked with themselves and with the casein micelles using transglutaminase thus paralleled the effect of heat treatment on acid gelation. It further seems that the enzymatic cross-linking of heat-induced whey protein complexes increases the elasticity of the resulting acid gels by increasing rigidity of the complexes (Eissa and Khan 2005) or by enhancing their interaction with the casein micelles (Bonisch et al. 2005).

On all the above-listed interactions, intra- and inter-particles covalent disulphide bonds are probably the ones that are most susceptible to affect the viscoelastic moduli or the "solid-like" behaviour of the acid milk gels. In our point of view, one choice for future investigation could then be to study the effect of the balance 
between the content in disulphide bonds inside the heat-induced whey protein $/ \mathrm{K}$ casein complexes and in thiol groups available for the formation of inter-particle disulphide bonds on the acid gelation of milk.

3.3 Possible methods to modify the size of the heat-induced whey protein/K-casein complexes

Because they are thought to act as spacers or bridges between the casein micelles on acid gelation (Donato et al. 2007a; Lucey et al. 1999, 1998a), the size of the whey protein/K-casein heat-induced complexes are quite likely to play a key role in the final microstructure of the acid gel, by affecting, e.g. pore size and connectivity (Kalab et al. 1983; Parnell-Clunies et al. 1987). Naturally, the serum form of complexes has hydrodynamic diameters ranging 30-100 $\mathrm{nm}$ and molecular weight values of $\sim 4.10^{6}$ to $2.10^{7}$ g.mol ${ }^{-1}$ (Donato and Guyomarc'h 2009). In a different field, microparticulated whey protein having sizes of $0.1-2 \mu \mathrm{m}$ can be used to control firmness and syneresis of yoghurt gels (Janhøj and Ipsen 2006; SandovalCastilla et al. 2004). However, little is known of how the size of the whey protein/Kcasein complexes can affect the properties of acid milk gels.

By increasing the $\mathrm{pH}$ of heat treatment of milk from 6.5 to 7.1 (Anema et al. 2004; Rodriguez del Angel and Dalgleish 2006), acid gels with increased final G' values are produced, although a decrease is found at $\mathrm{pH} \geq 7.2$. Among other reasons, slightly alkaline $\mathrm{pH}$ conditions of heating are known to yield whey protein/ $\mathrm{K}$-casein complexes of smaller size than at pH 6.5 (Creamer et al. 1978; Rodriguez del Angel and Dalgleish 2006; Vasbinder and de Kruif 2003). However, the complexes produced at pH 7.1 may also contain more disulphide bonds or active thiol groups, which can both affect the texture of acid gel more than their size (Alting et al. 2003). Similarly, Britten and Giroux (2001) produced smaller complexes in solutions of WPI at $\mathrm{pH} 8.5$ than 6.5 , but failed to correlate size and $\mathrm{G}^{\prime}$ values of the resulting acid gels.

On the other hand, by decreasing the casein to whey protein ratio of milk blends, Guyomarc'h et al. (2003a), Puvanenthiran et al. (2002) or Beaulieu et al. (1999) increased the size of complexes up to fivefold and obtained acid gels with proportionally increased final $G$ ' values. In model whey protein systems, higher protein concentration also promotes formation of larger complexes (Hoffmann et al. 1997; Ju and Kilara 1998b; Le Bon et al. 1999). In milk, increasing the concentration of only the whey protein using membrane separation techniques promotes their heat denaturation (Mc Mahon et al. 1993; Oldfield et al. 2005), but the likely effect on aggregate size is yet to be established.

In skim milk, increasing the temperature and/or duration of heat treatment increases the extent of denaturation of the whey proteins (Dannenberg and Kessler 1988c), with proportional consequences on the final firmness and water retention capacity of the acid gel (Anema et al. 2004; Dannenberg and Kessler 1988a, d). Unfortunately, no similar abacuses have been produced to know how the size of the heat-induced whey protein/K-casein polymers varies with time and temperature of heating. It is however known from model whey protein systems that both factors positively affect the size of heat-induced whey protein polymers (Hoffmann et al. 1997; Le Bon et al. 1999; Schokker et al. 2000). 
Investigations on the heat-aggregation behaviour of $\beta-\mathrm{LG}$ or WPI model solutions clearly show that of all factors, the control of electrostatic repulsion between the reactant proteins affects the final size of the heat-induced complexes. As a rule, increasing the ionic strength of the medium decreases the range and intensity of electrostatic repulsion, thus increasing the chance for aggregation, and the size of complexes (Baussay et al. 2004; Caussin and Bouhallab 2004; Durand et al. 2002; Mahmoudi et al. 2007; Pouzot et al. 2005; Unterhaslberger et al. 2006; Xiong 1992). Also, having the $\mathrm{pH}$ close to the $\mathrm{p} I$ of the reactant whey proteins enhances aggregation and yield larger, clustered complexes (Foegeding et al. 2002; Mehalebi et al. 2008; Vasbinder and de Kruif 2003).

Due to (a) their effective charge screening, (b) the possible induction of conformational changes in the protein and (c) their ability to bind carboxylate groups, calcium ions have long been acknowledged to promote protein aggregation (Ju and Kilara 1998a; Simons et al. 2002). Parris et al. (1997) or Xiong (1992) reported the enhanced formation of aggregates when increasing ionic calcium concentration in whey or whey isolate prior to heating. Caussin et al. (2003) further showed that heating WPI in presence of $10 \mathrm{mmol} . \mathrm{L}^{-1} \mathrm{CaCl}_{2}$ yielded larger heatinduced complexes than with 100 mmol. $\mathrm{L}^{-1} \mathrm{NaCl}$, further demonstrating the specific promoting effect of the divalent cation on aggregation. However, this effect is highly dependent on pH (Britten and Giroux 2001). Simons et al. (2002) and Mounsey and O'Kennedy (2007) found that a stoichiometry of about 0.1 to $0.165 \mathrm{mmol} \mathrm{Ca}^{2+}$ per $\mathrm{g}$ $\beta-\mathrm{LG}$ is necessary to trigger significant heat aggregation. The conditions for maximum aggregation of WPI also seem to obey some stoichiometry, albeit the ratio of mmol $\mathrm{Ca}^{2+}$ per $\mathrm{g}$ protein varies across studies (Ju and Kilara 1998a; Sherwin and Foegeding 1997). Simons et al. (2002) explained that heat-induced complex formation could occur only when the repulsive charges born by the carboxyl groups of the whey proteins were shielded by calcium counterions through specific binding.

Studies on the effect of ionic strength or ions have generally been performed on model solutions. To the authors' knowledge, these factors have not been tested in milk as a means to vary the size of the heat-induced whey protein/K-casein complexes. O'Kennedy and Mounsey (2009) however reported that the heat-induced aggregation behaviour of the $\beta$-LG largely differed whether the protein was in presence of sodium, calcium or phosphate ions; or of mixes of them; or of simulated milk ultrafiltrate. They insisted that the response of the heat-induced formation of whey protein complexes to ionic strength should be dramatically different in a medium where ionic species are in equilibrium with each other or with the casein micelles. In skim milk whose sodium or calcium contents were varied prior to heat treatment, Farrag et al. (2001) and Ramasubramanian et al. (2008) reported only marginal changes in the resulting acid gelation behaviour. Conversely, dramatic changes are reported when micelle-bound colloidal calcium phosphate is modulated prior to heating (Famelart et al. 2009; Ozcan-Yilsay et al. 2008). All these results suggest that understanding the effect of ionic strength or minerals on the heat-induced whey protein/K-casein complex formation in milk cannot be anticipated from results obtained in model solutions, and therefore, needs dedicated research.

Eventually, the size of the heat-induced whey protein/K-casein complexes may be controlled through the use of stabilising molecules. In recent years, research has 
evidenced that caseins may help stabilise heat-denatured globular proteins from whey or egg in a pattern that resembles chaperone activity (Bhattacharyya and Das 1999). In the presence of casein material, turbidity of the heated globular protein solution is reduced as a result of decreased aggregate size (Khodarahmi et al. 2008; Koudelka et al. 2009; Matsudomi et al. 2004; Morgan et al. 2005; O'Kennedy and Mounsey 2006; Yong and Foegeding 2010; Zhang et al. 2005). In the case of coheated K-casein and WPI, smaller and more numerous mixed complexes were produced with increasing proportion of K-casein (Guyomarc'h et al. 2009b).

Other studies also indicated that ligands or surfactants like arginine, guanidium, lecithins, SDS or sodium laurate could control over-aggregation of heat-induced complexes of milk proteins (Tran Le et al. 2007; Unterhaslberger et al. 2006). Kerstens et al. (2005) reported a peculiar effect of the non-ionic surfactant Tween 20, which promotes formation of $\mu \mathrm{m}$-large, spherical, sizedesigned, reversible heat-induced aggregates in concentrated $\beta-\mathrm{LG}$ solutions. Studies that control aggregation of $\beta$-LG using coacervation with carbohydrates are out of the scope of the review.

In conclusion, numerous methods are available that could probably be transferred to the soluble heat-induced whey protein/K-casein complexes to modulate their size. However, only a very few of them have been applied to study the effect of the size of these specific complexes on the acid gelation of milk. In essence, the available studies rather investigated the effect of the size of larger microparticulated whey proteins, used as fat replacers, in acid milk gels.

3.4 Possible methods to modify the shape of the heat-induced whey protein $/ \mathrm{K}$-casein complexes

Thanks to the large amount of reports that have described the aggregation behaviour of proteins in varying conditions, it now emerges that almost, if not all the proteins are able to alternatively heat-aggregate into branched particulate clusters or into elongated fibres depending on the distribution of functional sites across their exposed surface. As a rule, environmental conditions that promote exposure of local poles of high net charges and/or $\beta$-sheet structure also promotes head-to-tail aggregation, hence fibrillation. Hence, various studies have reported that globular proteins such as ovalbumin (Weijers et al. 2008), $\beta$-LG (Bolder et al. 2007; Durand et al. 2002; Ikeda and Morris 2002; Jung et al. 2008), BSA (Holm et al. 2007) or partially hydrolysed $\alpha$-LA (Otte et al. 2005) can yield fibrils on (even moderate) heat treatment at low ionic strength values and at $\mathrm{pH}$ generally $\sim 7.0$ or $\sim 2.0$ depending on proteins. Elongated particles of $\beta$-LG can further be produced in water at $\mathrm{pH} \sim 7.0$ and $\leq 50 \mathrm{mmol} . \mathrm{L}^{-1} \mathrm{NaCl}$ (Alting et al. 2004; Pouzot et al. 2005). Fibrillation can also occur in acidic solutions of WPI (Akkermans et al. 2008), yielding somewhat thicker structures than with pure $\beta$-LG (Ikeda and Morris 2002). Bolder et al. (2007) however suggested that although other species were present in solution, $\beta-\mathrm{LG}$ alone is involved in fibrillation when heating WPI. Because of the often acidic $\mathrm{pH}(\sim 2.0)$ and orientation constraints, thiol/disulphide exchanges do not seem to contribute to fibril formation, but readily occur when the fibrils are brought to $\mathrm{pH} 7$ to 10 (Bolder et al. 2007). Alternatively, Rasmussen et al. (2007) could produce fibres of $\beta-\mathrm{LG}$ after prolonged exposure to subdenaturing 
concentrations of chaotropes and showed that their content in disulphide covalent bonds could be modulated depending on whether urea or potassium thiocyanate was used as the chaotrope.

Fibrils in WPI solutions were shown to increase the viscosity of the system and to exhibit shear-thinning behaviour (Akkermans et al. 2008). Veerman et al. (2003) compared the ability of long linear fibrils formed by heating $\beta-\mathrm{LG}$ at $\mathrm{pH} 2$ then brought to $\mathrm{pH} 7$ to yield a gel on addition of $\mathrm{CaCl}_{2}$ to that of random $\beta$-LG complexes conventionally produced by heat treatment at $\mathrm{pH}$. They showed that the fibrils were able to build a solid gel at much lower protein concentrations than the control complexes. Alting et al. (2004) furthermore mentioned that long fibrillar structures of ovalbumin significantly contribute to the firmness of acid-induced gels. If they could be produced in milk in technological conditions, fibrillar whey protein/ $\mathrm{K}$-casein complexes would most likely help increasing firmness of the acid dairy gels, even if anisotropic structures generally involve less intermolecular thiol/ disulphide exchanges (Broersen et al. 2007; Weijers et al. 2008) otherwise desirable to gel firmness (Alting et al. 2003, 2004).

Of all caseins, the $\mathrm{K}$-casein is also capable of forming fibrils in physiological

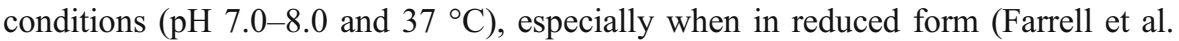
2003; Leonil et al. 2008; Thorn et al. 2005). In the case of $\mathrm{K}$-casein, the driving force for fibrillation of the protein is not known, but likely involves intermolecular $\beta$-sheet stacking (Thorn et al. 2009). When WPI and $\mathrm{k}$-casein are heated together at $\mathrm{pH} 7.0$ and $0.1 \mathrm{~mol} . \mathrm{L}^{-1} \mathrm{NaCl}$, the heat-induced whey protein/K-casein complexes turn from particles with a fractal dimension $D f$ of $\sim 2$ to linear structures with $D f \sim 1.1$ as the proportion of K-casein exceeds $0.5 \mathrm{~g}$ per g WPI (Guyomarc'h and Nicolai, 2009, personal communication, Fig. 1). In milk phase conditions, the protein composition and more specifically the respective proportions of $\mathrm{k}$-casein and whey proteins may therefore be an efficient means to control the shape of the heat-induced whey protein/ $\mathrm{k}$-casein complexes.

However, as $\alpha$ s or $\beta$-caseins inhibit fibrillation of the $k$-casein (Thorn et al. 2005) or that of globular proteins, including the whey proteins (see review paper by Yong and Foegeding (2010)), preparation of elongated whey protein/K-casein heat-induced complexes may first rather be attempted in whey, prior to their addition to milk. Interestingly, Creamer et al. (1978) early reported that the heat-induced whey protein/ $\mathrm{K}$-casein complexes that formed in milk at $\mathrm{pH} 6.8$ were more thread-like than those produced at $\mathrm{pH}$ 6.5. Since the involvement of $\mathrm{k}$-casein into the whey protein/ $\mathrm{K}$-casein complexes of milk seems to increase as the $\mathrm{pH}$ of heating increases (Anema 2007; Donato and Dalgleish 2006), it is possible that the shape of the complexes may be somewhat controlled in situ through varying the $\mathrm{K}$-casein to whey protein ratio of milk or its $\mathrm{pH}$ of heating. In the long term, the ratio can also be genetically modified in mammals (Jimenez-Flores and Richardson 1988).

Although fibrillar complexes may be desirable for texture, there is suspicion that they could be cytotoxic (Hudson et al. 2009). Control of their extension might therefore be useful. Alternative to the involvement of chaperone caseins, the use of chemical grafting of additional reactive sulfhydryl groups onto ovalbumin molecules in solution at $\mathrm{pH} 7.0$ and $0.15 \mathrm{M} \mathrm{NaCl}$ has been shown to yield more branched, amorphous heat-induced complexes as opposed to more fibrillar structures (Broersen et al. 2006). Genetically or chemically modified $\beta-L G$ with added free thiol groups 
may be a good means to increase branching of the heat-induced whey protein/Kcasein complexes, but this is yet to be demonstrated. Reduction or disruption of natural disulphide bonds (Bazinet et al. 1997; Kella et al. 1989) may also open routes for branching. Although goat or sheep K-caseins contain three cysteines, they all seem to be naturally involved into disulphide bonds (Bouguyon et al. 2006) and hence, are unlikely to promote branching.

To the authors' point of view, building acid milk gels in the presence of heatinduced whey protein/K-casein in the form of fibrils that should entangle with each

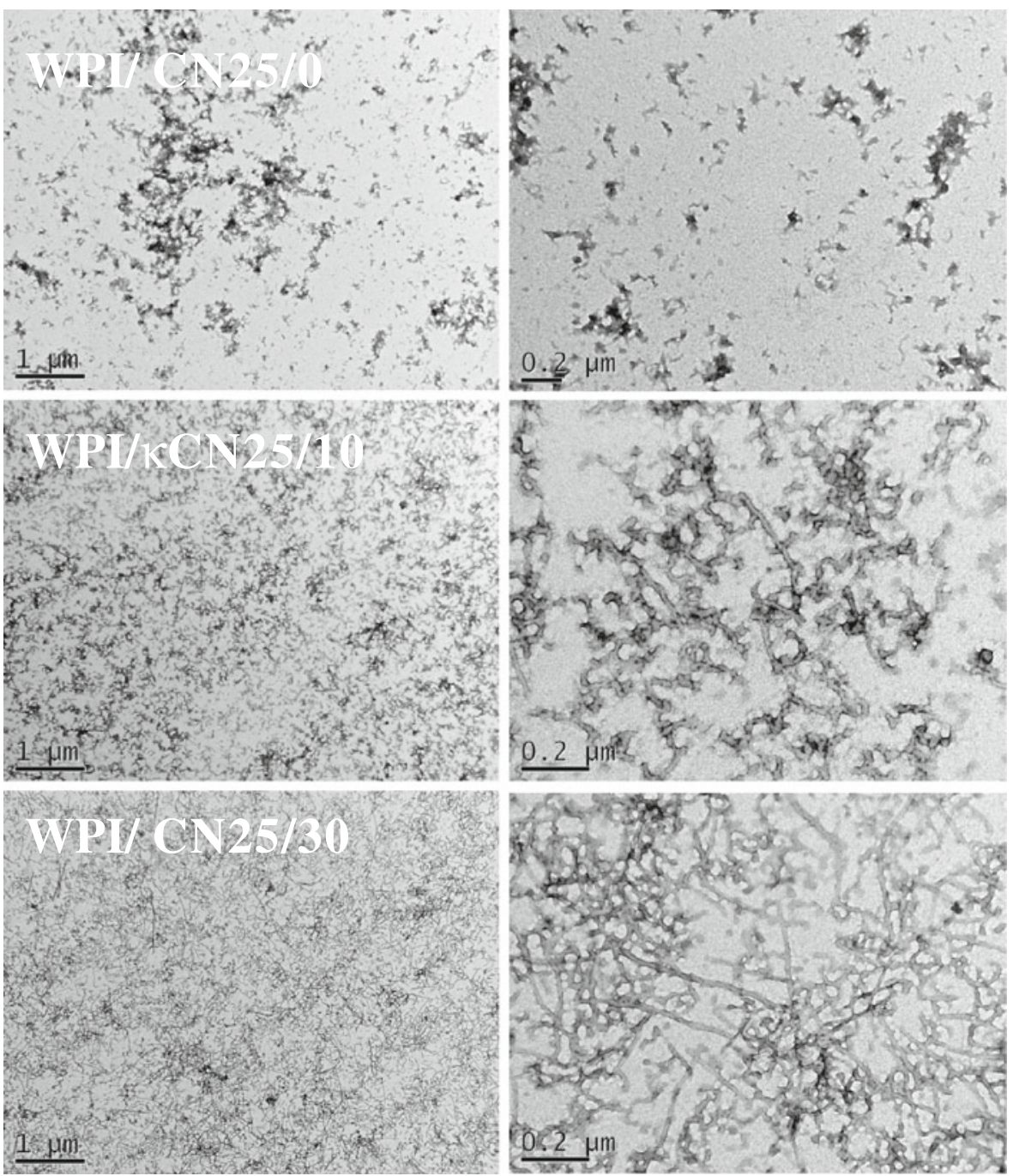

Fig. 1 Transmission electron micrographs of heated $\left(80^{\circ} \mathrm{C} / 24 \mathrm{~h}\right)$ solutions of $25 \mathrm{~g} . \mathrm{kg}^{-1} \mathrm{whey}$ protein isolate (WPI) and 0-30 g.kg ${ }^{-1}$ isolated freeze-dried $\mathrm{K}$-casein $(\mathrm{KCN})$ in 0.1 mol. $\mathrm{L}^{-1} \mathrm{NaCl}, \mathrm{pH} 7.0$, prepared as in Guyomarc'h et al. (2009b) 
other and provide numerous interaction patches with the casein micelles is very likely to strongly affect the texture of the gels. Although a lot of proteins are able to form fibrils on heat treatment depending on conditions, to the author's knowledge no attempt has however yet been undertaken to evaluate the effect of heat-induced whey protein or whey protein/K-casein fibrils on the acid gelation of milk systems.

\subsection{Possible methods to modify the water holding capacity of the heat-induced} whey protein/K-casein complexes

It is largely known that the essential factor to improve water holding capacity of acid milk gels is to fully denature the whey protein (Dannenberg and Kessler 1988d). Conversely to gel firmness, the water holding capacity of yoghurt gel linearly increases with heating, including UHT conditions (Krasaekoopt et al. 2003). At temperatures above $100{ }^{\circ} \mathrm{C}$, de Wit (2009) mentions that specific unfolding occurs, possibly as a result of disulphide breakdown that may favour protein hydration (see also section 3.1). It is therefore possible that heat-induced whey protein $/ \mathrm{K}$-casein complexes with less mechanical resistance but higher water holding capacity are formed in UHT conditions.

A higher whey protein to casein ratio in the milk has also been associated with increased water holding capacity of the yoghurt gel (Puvanenthiran et al. 2002; Schorsch et al. 2001) although it is not clear whether the actual composition of the heat-induced complexes, rather than their size or concentration or shape, is responsible for this change. However, Guyomarc'h et al. (2009b) showed that model heat-induced complexes of WPI were less dense when involving $\mathrm{K}$-casein, hence more likely to uptake water through a more porous structure.

The addition of charges (see section 2.2) to the heat-induced complexes may also be a way to improve water binding, providing that the complexes keep destabilising into a gel on acidification. In that sense, the covalent binding of sugars to milk protein has been shown to enhance solubility but also gelation, depending on extent (Oliver et al. 2006). Glycosylation of a peculiar heat-induced whey protein ingredient using dextran molecules was shown to increase its water-binding capacity when re-heated (Lillard et al. 2009). The application of controlled glycosylation of whey protein/K-casein complexes to yoghurt making is however yet to be investigated.

The presence of counterions that would shield electrostatic repulsion during the formation of thiol/disulphide complexes may be another way to modulate the density of soluble whey proteins/K-casein complexes. In their review on whey protein functionality, Foegeding et al. (2002) mentioned that gels made of WPI heated in the presence of salts are denser, coarser and more permeable than at low ionic strength. Pouzot et al. (2005) furthermore showed that heating $\beta$-LG at neutral $\mathrm{pH}$ in the presence of 200 mmol. $\mathrm{L}^{-1} \mathrm{NaCl}$ yielded denser $\beta$-LG covalent complexes than at lower ionic strength values. As another example, Giroux et al. (2010) performed the cold-set precipitation of WPI preheated at neutral $\mathrm{pH}$ and low ionic strength using a $\mathrm{pH}$ cycling to $\mathrm{pH} 5-6$ in the presence of increasing concentrations of $\mathrm{CaCl}_{2}$, to produce disulphide complexes of whey proteins having correspondingly increasing density, hence decreased water retention capacity. 
On top of increasing polymerisation and gel strength, free thiol groups also seem to be a factor to control syneresis in acid gels. Lee et al. (1994) added recombinant $\beta$-LG with two or three free thiol groups to skim milk $\left(<1 \mathrm{~g} . \mathrm{kg}^{-1}\right)$ and observed reduced syneresis in the yoghurt produced after heat treatment and fermentation of the modified milk. Possibly, addition of thiol groups promoted branching and hence, reticulated porous complexes that could easily carry water.

\section{Perspectives for research}

First, this review was wilfully limited to the production of whey protein or whey protein/K-casein complexes using heat treatment, but other technological means could be considered such as high pressure treatments or dry heating of protein powders. These technologies have been reported to induce whey protein denaturation and complex formation, but with few similarities with the heat treatment (Considine et al. 2007; Ibrahim et al. 1993; Zhou et al. 2008). They could therefore be used in combination with or in substitution to heating, to potentially modulate the properties of the whey protein/K-casein complexes. The resulting complexes could also be further modified, using a number of the chemical or biological methods listed in the present review.

The present overview of the literature further evidences two major fields for future investigation of the role of the heat-induced complexes in the acid gelation of milk. First, a large number of the reviewed chemical, biological or physical means to modulate the physico-chemical properties of protein material has often been applied on single, native proteins rather than on proteins assemblies like the heat-induced complexes. But modification of the reactant protein is quite likely to affect its aggregation on heat treatment, hence to introduce many other large changes than the initial modification. Therefore, modifying the constituted heat-induced whey protein/ $\mathrm{K}$-casein complexes as a means to vary their interaction properties may prove an interesting scientific strategy.

Second, where as a majority of the studies using modified proteins or modified complexes have investigated the consequences on thermal gels, only a little proportion of them considered acid gelation. Amongst them, only a little number of studies investigated as complex a system as milk (see, e.g. Lieske (1999); Vidal et al. (1998) who modified the casein micelle). In the perspective of better understanding the role of the heat-induced whey protein/K-casein in the acid gelation of skim milk, we therefore propose to modulate some targeted properties of the complexes, using the presently reviewed methods, then to introduce them into milk where their capacity to establish specific interactions, or to build specific microstructures, will be tested. Should some of these methods be particularly efficient in affecting the acid gelation of milk, their application could then be attempted directly on milk. However, this raises the issue of correlated changes in the milk, for instance through changes in the composition and equilibrium of milk if ions or $\mathrm{pH}$ or exogenous proteins are used to modify the whey protein $/ \mathrm{K}$-casein soluble complexes in situ or through the simultaneous modifications of the whey protein/K-casein complexes and the casein micelles if, e.g. chemical grafting is used to modify the soluble complexes in situ. Demonstration of the transferability of the 
presently reviewed methods, directly to the milk system, is therefore in itself a critical perspective for applicative research.

Acknowledgements Author Marion Morand acknowledges the financial support from Région Bretagne, under the grant ARED 4298. Author Fanny Guyomarc'h thanks Cédric Gaillard, INRA, Nantes, for taking the TEM pictures of Fig. 1.

\section{References}

Akkermans C, van der Goot AJ, Venema P, Van der Linden E, Boom RM (2008) Properties of protein fibrils in whey protein isolate solutions: microstructure, flow behaviour and gelation. Int Dairy $\mathrm{J}$ 18:1034-1042

Alexander M, Dalgleish DG (2005) Interactions between denatured milk serum proteins and casein micelles studied by diffusing wave spectroscopy. Langmuir 21:11380-11386

Allmere T, Andren A, Björck L (1997) Interactions between different genetic variants of $\beta$-lactoglobulin and K-casein A during heating of skim milk. J Agric Food Chem 45:1564-1569

Allmere T, Andrén A, Lindersson M, Björck L (1998a) Studies on rheological properties of stirred milk gels made from milk with defined genetic variants of $\mathrm{K}$-casein and $\beta$-lactoglobulin. Int Dairy J 8:899-905

Allmere T, Andren A, Lunden A, Björck L (1998b) Interactions in heated skim milk between genetic variants of $\beta$-lactoglobulin and K-casein. J Agric Food Chem 46:3004-3008

Alting AC, De Jongh HHJ, Visschers RW, Simons J-WFA (2002) Physical and chemical interactions in cold gelation of food proteins. J Agric Food Chem 50:4682-4689

Alting AC, Hamer RJ, de Kruif CG, Paques M, Visschers RW (2003) Number of thiol groups rather than the size of aggregates determines the hardness of cold set whey protein gels. Food Hydrocoll 17:469-479

Alting AC, Weijers M, de Hoog EHA, van de Pijpekamp AM, Stuart MAC, Hamer RJ, de Kruif CG, Visschers RW (2004) Acid-induced cold gelation of globular proteins: effects of protein aggregates characteristics and disulfide bonding on rheological properties. J Agric Food Chem 52:623-631

Anema SG (1997) The effect of chymosin on K-casein-coated polystyrene latex particles and bovine casein micelles. Int Dairy J 7:553-558

Anema SG (2007) Role of K-casein in the association of denatured whey proteins with casein micelles in heated reconstituted skim milk. J Agric Food Chem 55:3635-3642

Anema SG, Li Y (2000) Further studies on the heat-induced, pH dependent dissociation of casein from the micelles in reconstituted skim milk. Lebensm Wiss Technol (Food Sci Technol) 33:335-343

Anema SG, McKenna AB (1996) Reaction kinetics of thermal denaturation of whey proteins in heated reconstituted whole milk. J Agric Food Chem 44:422-428

Anema SG, Lee SK, Lowe EK, Klostermeyer H (2004) Rheological properties of acid gels prepared from heated pH-adjusted skim milk. J Agric Food Chem 52:337-343

Anema SG, Lee SK, Klostermeyer H (2007) Effect of pH at heat treatment on the hydrolysis of K-casein and the gelation of skim milk by chymosin. LWT Food Sci Technol 40:99-106

Banon S, Hardy J (1992) A colloidal approach of milk acidification by glucono-delta-lactone. J Dairy Sci 75:935-941

Baussay K, Le Bon C, Nicolai T, Durand D, Busnel J-P (2004) Influence of the ionic strength on the heatinduced aggregation of the globular protein $\beta$-lactoglobulin at $\mathrm{pH}$ 7. Int $\mathrm{J}$ Biol Macromol 34:21-28

Bazinet L, Lamarche L, Boulet M, Amiot J (1997) Combined effects of $\mathrm{pH}$ and temperature during electroreduction of whey proteins. J Agric Food Chem 45:101-107

Beaulieu M, Pouliot Y, Pouliot M (1999) Thermal aggregation of whey proteins in models solutions as affected by casein/whey protein ratios. J Food Sci 64:776-780

Bhattacharyya J, Das KP (1999) Molecular chaperone-like properties of an unfolded protein, as-casein. J Biol Chem 274:15505-15509

Bikker JF, Anema SG, Li Y, Hill JP (2000) Rheological properties of acid gels prepared from heated milk fortified with whey protein mixtures containing the $\mathrm{A}, \mathrm{B}$ and $\mathrm{C}$ variants of $\beta$-lactoglobuline. Int Dairy J 10:723-732

Boenisch MP, Huss M, Weld K, Kulozik U (2007) Transglutaminase cross-linking of milk proteins and impact on yoghurt gel properties. Int Dairy J 17:1360-1371 
Bolder SG, Vasbinder AJ, Sagis LMC, van der Linden E (2007) Heat-induced whey protein isolate fibrils: conversion, hydrolysis, and disulphide bond formation. Int Dairy J 17:846-853

Bonisch M, Kulozik U, Hub M, Morita A (2005) Method of producing yogurt, Patent No. WO2005/110108

Bonisch MP, Huss M, Lauber S, Kulozik U (2007) Yoghurt gel formation by means of enzymatic protein cross-linking during microbial fermentation. Food Hydrocoll 21:585-595

Bouguyon E, Beauvallet C, Huet J-C, Chanat E (2006) Disulphide bonds in casein micelle from milk. Biochem Biophys Res Commun 343:450-458

Bouhallab S, Morgan F, Henry G, Molle D, Leonil J (1999) Formation of stable covalent dimer explains the high solubility at $\mathrm{pH} 4.6$ of lactose- $\beta$-lactoglobulin conjugates heated near neutral $\mathrm{pH}$. J Agric Food Chem 47:1489-1494

Bovetto LJR, Schmitt CJE, Beaulieu M, Carlier N, Unterhaslberger G (2007) Nanoparticulated whey proteins, Patent No. US 2007/0231453 A1

Britten M, Giroux HJ (2001) Acid-induced gelation of whey protein polymers: effects of $\mathrm{pH}$ and calcium concentration during polymerization. Food Hydrocoll 15:609-617

Broersen K, van Teeffelen AMM, Vries A, Voragen AGJ, Hamer RJ, De Jongh HHJ (2006) Do sulfhydryl groups affect aggregation and gelation properties of ovalbumin? J Agric Food Chem 54:5166-5174

Broersen K, Weijers M, de Groot J, Hamer RJ, De Jong HHJ (2007) Effect of protein charge on the generation of aggregation-prone conformers. Biomacromolecules 8:1648-1656

Calvo MM, Leaver J, Banks JM (1993) Influence of other whey proteins on the heat-induced aggregation of $\alpha$-lactalbumin. Int Dairy J 3:719-727

Carbonaro M, Bonomi F, Iametti S, Carnovale E (1996) Modifications in disulfide reactivity of milk induced by different pasteurization conditions. J Food Sci 61:495-499

Cases E, Vidal V, Cuq J-L (2003) Effect of the K-casein deglycosylation on the acid coagulability of milk. J Food Sci 68:2406-2410

Caussin F, Bouhallab S (2004) Environnement minéral et propriétés fonctionnelles des protéines sériques [Mineral environment and functional properties of whey proteins]. In: Gaucheron F (ed) Minéraux et produits laitiers. Tec et Doc, Londres, England, pp 343-390

Caussin F, Famelart MH, Maubois JL, Bouhallab S (2003) Mineral modulation of thermal aggregation and gelation of whey proteins: from $\beta$-lactoglobulin model system to whey protein isolate. Lait 83:353364

Cayot P, Lorient D (1998) Structures et technofonctions des protéines du lait [Structures and technofunctional properties of dairy proteins]. Tec \& Doc, Lavoisier, Paris, France

Chakraborty A, Das N, Das KP, Halder UC (2009) Loss of structural integrity and hydrophobic ligand binding capacity of acetylated and succinylated bovine $\beta$-lactoglobulin. Int Dairy J 19:43-49

Chevalier F, Chobert JM, Popineau Y, Nicolas MG, Haertle T (2001) Improvement of functional properties of $\beta$-lactoglobulin glycated through the Maillard reaction is related to the nature of the sugar. Int Dairy J 11:145-152

Chobert JM, Gaudin JC, Dalgalarrondo M, Haertle T (2006) Impact of Maillard type glycation on properties of $\beta$-lactoglobulin. Biotechnol Adv 24:629-632

Considine T, Patel HA, Anema SG, Singh H, Creamer LK (2007) Interactions of milk proteins during heat and high hydrostatic pressure treatments - a review. Innov Food Sci Emerg Technol 8:1-23

Corzo-Martinez M, Moreno FJ, Olano A, Villamiel M (2008) Structural characterization of bovine $\beta$ lactoglobulin-galactose/tagatose Maillard complexes by electrophoretic, chromatographic, and spectroscopic methods. J Agric Food Chem 56:4244-4252

Creamer LK, Berry GP, Matheson AR (1978) The effect of $\mathrm{pH}$ on protein aggregation in heated skim milk. N Z J Dairy Sci Technol 13:9-15

Dalgleish DG (1990) Denaturation and aggregation of serum proteins and caseins in heated milk. J Agric Food Chem 38:1995-1999

Dalgleish DG (1998) Casein micelles as colloids: surface structures and stabilities. J Dairy Sci 81:30133018

Dannenberg F, Kessler HG (1988a) Effect of denaturation of $\beta$-lactoglobulin on texture properties of setstyle nonfat yoghurt. 2. Firmness and flow properties. Milchwissenschaft 43:700-704

Dannenberg F, Kessler HG (1988b) Reaction-kinetics of the denaturation of whey proteins in milk. J Food Sci 53:258-263

Dannenberg F, Kessler HG (1988c) Application of reaction-kinetics to the denaturation of whey proteins in heated milk. Milchwissenschaft 43:3-7

Dannenberg F, Kessler HG (1988d) Effect of denaturation of $\beta$-lactoglobulin on texture properties of setstyle nonfat yoghurt. 1. Syneresis. Milchwissenschaft 43:632-635 
de Jong P (1996) Modelling and optimization of thermal processes in the dairy industry, Ph.D. Dissertation, University of Delft, Delft, The Netherlands

de Kruif CG (1998) Supra-aggregates of casein micelles as a prelude to coagulation. J Dairy Sci 81:30193028

de Wit JN (2009) Thermal behaviour of bovine $\beta$-lactoglobulin at temperatures up to $150{ }^{\circ} \mathrm{C}$. A review. Trends Food Sci Technol 20:27-34

Denisov VP, Jonsson BH, Halle B (1999) Hydration of denatured and molten globule proteins. Nat Struct Biol 6:253-260

Donato L, Dalgleish DG (2006) Effect of $\mathrm{pH}$ of heating on the qualitative and quantitative compositions of the sera of reconstituted skim milks and on the mechanisms of formation of soluble aggregates. J Agric Food Chem 54:7804-7811

Donato L, Guyomarc'h F (2009) Formation and properties of the whey protein/K-casein complexes in heated skim milk — a review. Dairy Sci Technol 89:3-29

Donato L, Alexander M, Dalgleish DG (2007a) Acid gelation in heated and unheated milks: interactions between serum protein complexes and the surfaces of casein micelles. J Agric Food Chem 55:41604168

Donato L, Guyomarc'h F, Amiot S, Dalgleish DG (2007b) Formation of whey protein/K-casein complexes in heated milk: Preferential reaction of whey protein with $\mathrm{K}$-casein in the casein micelles. Int Dairy J 17:1161-1167

Durand D, Gimel JC, Nicolai T (2002) Aggregation, gelation and phase separation of heat denatured globular proteins. Phys Stat Mech Appl 304:253-265

Eissa AS, Khan SA (2005) Acid-induced gelation of enzymatically modified, preheated whey proteins. J Agric Food Chem 53:5010-5017

Faergemand M, Otte J, Qvist KB (1998) Cross-linking of whey proteins by enzymatic oxidation. J Agric Food Chem 46:1326-1333

Famelart MH, Tomazewski J, Piot M, Pezennec S (2003) Comparison of rheological properties of acid gels made from heated casein combined with $\beta$-lactoglobulin or egg ovalbumin. Int Dairy J 13:123134

Famelart MH, Tomazewski J, Piot M, Pezennec S (2004) Comprehensive study of acid gelation of heated milk with model protein systems. Int Dairy J 14:313-321

Famelart MH, Gauvin G, Paquet D, Brulé G (2009) Acid gelation of colloidal calcium phosphate-depleted preheated milk. Dairy Sci Technol 89:335-348

Farrag AF, Shahein NM, El-Din HMF (2001) Effect of calcium and sodium chloride on the acid induced gelation of raw and heated milk, in: 8th Egyptian Conference for Dairy Science and Technology. Egyptian Society of Dairy Science, Cairo, Egypt, pp 103-118

Farrell HM, Cooke PH, Wickham ED, Piotrowski EG, Hoagland PD (2003) Environmental influences on bovine K-casein: reduction and conversion to fibrillar (amyloid) structures. J Prot Chem 22:259-273

Farrell HM, Jimenez-Flores R, Bleck GT, Brown EM, Butler JE, Creamer LK, Hicks CL, Hollar CM, NgKwai-Hang KF, Swaisgood HE (2004) Nomenclature of the proteins of cows' milk - sixth revision. J Dairy Sci 87:1641-1674

Fernandes PA, Ramos MJ (2004) Theoretical insights into the mechanism for thiol/disulfide exchange. Chem Eur J 10:257-266

Foegeding EA, Davis JP, Doucet D (2002) Mc Guffey M.K., Advances in modifying and understanding whey protein functionality. Trends Food Sci Technol 13:151-159

Gallagher DP, Mulvihill DM (1997) Heat stability and renneting characteristics of milk systems containing bovine casein micelles and porcine or bovine $\beta$-lactoglobulin. Int Dairy J 7:221-228

Gastaldi E, Lagaude A, Tarodo de la Fuente B (1996) Micellar transition state in casein between pH 5.5 and 5.0. J Food Sci 61:59-68

Gatti C, Risso PH, Pires MS (1995) Spectrofluorometric study on surface hydrophobicity of bovine casein micelles in suspension and during enzymatic coagulation. J Agric Food Chem 43:2339-2344

Gauche C, Tomazi T, Barreto PLM, Ogliari PJ, Bordignon-Luiz MT (2009) Physical properties of yoghurt manufactured with milk whey and transglutaminase. LWT Food Sci Technol 42:239-243

Gerbanowski A, Rabiller C, Larré C, Guéguen J (1999) Grafting of aliphatic and aromatic probes on bovine serum albumin: influence on its structural and physicochemical characteristics. J Prot Chem $18: 325-336$

Giroux HJ, Britten M (2004) Heat treatment of whey proteins in the presence of anionic surfactants. Food Hydrocoll 18:685-692

Giroux HJ, Houde J, Britten M (2010) Preparation of nanoparticles from denatured whey protein by $\mathrm{pH}-$ cycling treatment. Food Hydrocoll 24:341-346 
Goddard SJ (1996) Effect of thiol reagents on the acid-heat-induced gelation of high-heat skim milk. J Dairy Res 63:639-642

Graveland-Bikker JF, Anema SG (2003) Effect of individual whey proteins on the rheological properties of acid gels prepared from heated skim milk. Int Dairy J 13:401-408

Guyomarc'h F (2006) Formation of heat-induced protein aggregates in milk as a means to recover the whey protein fraction in cheese manufacture, and potential of heat-treating milk at alkaline $\mathrm{pH}$ values in order to keep its rennet coagulation properties. A review. Lait 86:1-20

Guyomarc'h F, Gueguiner C, Law AJR, Horne DS, Dalgleish DG (2003a) Role of the soluble and micellebound heat-induced protein aggregates on network formation in acid skim milk gels. J Agric Food Chem 51:7743-7750

Guyomarc'h F, Law AJR, Dalgleish DG (2003b) Formation of soluble and micelle-bound protein aggregates in heated milk. J Agric Food Chem 51:4652-4660

Guyomarc'h F, Renan M, Chatriot M, Gamerre V, Famelart MH (2007) Acid gelation properties of heated skim milk as a result of enzymatically induced changes in the micelle/serum distribution of the whey protein/K-casein aggregates. J Agric Food Chem 55:10986-10993

Guyomarc'h F, Jemin M, Le Tilly V, Madec MN, Famelart MH (2009a) Role of the heat-induced whey protein/K-casein complexes in the formation of acid milk gels: a kinetic study using rheology and confocal microscopy. J Agric Food Chem 57:5910-5917

Guyomarc'h F, Nono M, Nicolai T, Durand D (2009b) Heat-induced aggregation of whey proteins in the presence of K-casein or sodium caseinate. Food Hydrocoll 23:1103-1110

Halbert C, O'Kennedy BT, Hallihan A, Kelly PM (2000) Stabilisation of calcium phosphate using denatured whey proteins. Milchwissenschaft 55:386-389

Hattori M, Miyakawa S, Ohama Y, Kawamura H, Yoshida T, To O, Kuriki T, Takahashi K (2004) Reduced immunogenicity of $\beta$-lactoglobulin by conjugation with acidic oligosaccharides. J Agric Food Chem $52: 4546-4553$

Heertje I, Visser J, Smits P (1985) Structure formation in acid milk gels. Food Microstruct 4:267-277

Hiller B, Lorenzen PC (2008) Surface hydrophobicity of physicochemically and enzymatically treated milk proteins in relation to techno-functional properties. J Agric Food Chem 56:461-468

Hinrichs J, Keim S (2007) Process-induced stabilizing bonds in fermented milk products. Milchwissenschaft $62: 422-425$

Hinrichs R, Gotz J, Noll M, Wolfschoon A, Eibel H, Weisser H (2004) Characterisation of different treated whey protein concentrates by means of low-resolution nuclear magnetic resonance. Int Dairy $\mathrm{J}$ 14:817-827

Hoffmann MAM, van Mil PJJM (1999) Heat-induced aggregation of $\beta$-lactoglobulin as a function of $\mathrm{pH}$. J Agric Food Chem 47:1898-1905

Hoffmann MAM, van Mil PJJM (1997) Heat-induced aggregation of $\beta$-lactoglobulin: role of the free thiol group and disulfide bonds. J Agric Food Chem 45:2942-2948

Hoffmann MAM, Sala G, Olieman C (1997) deKruif K.G., Molecular mass distributions of heat-induced $\beta$-lactoglobulin aggregates. J Agric Food Chem 45:2949-2957

Holm NK, Jespersen SK, Thomassen LV, Wolff TY, Sehgal P, Thomsen LA, Christiansen G, BeyschauAdersen C, Knudsen AD, Otzen DE (2007) Aggregation and fibrillation of bovine serum albumin. Biochim Biophys Acta 1774:1128-1138

Holt C, Horne DS (1996) The hairy casein micelle: evolution of the concept and its implications for dairy technology. Neth Milk Dairy J 50:85-111

Horne DS (1998) Casein interactions: casting light on the black boxes, the structure in dairy products. Int Dairy J 8:171-177

Horne DS (2003) Casein micelles as hard spheres: limitations of the model in acidified gel formation. Colloids Surf A 213:255-263

Hudson SA, Ecroyd H, Dehle FC, Musgrave IF, Carver JA (2009) (-)-epigallocatechin-3-gallate (EGCG) maintains $\mathrm{K}$-casein in its prefibrillar state without redirecting its aggregation pathway. J Mol Biol 392:689-700

Ibrahim HR, Kobayashi K, Kato A (1993) Improvement of the surface functional-properties of $\beta$ lactoglobulin and $\alpha$-lactalbumin by heating in a dry state. Biosci Biotechnol Biochem 57:1549-1552

Ikeda S, Morris VJ (2002) Fine-stranded and particulate aggregates of heat-denatured whey proteins visualized by atomic force microscopy. Biomacromolecules 3:382-389

Jang HD, Swaisgood HE (1990) Disulfide bond formation between thermally denatured $\beta$-lactoglobulin and $\mathrm{K}$-casein in casein micelles. J Dairy Sci 73:900-904

Janhøj T, Ipsen R (2006) Effect of pre-heat treatment on the functionality of microparticulated whey protein in acid milk gels. Milchwissenschaft 61:131-134 
Jayat D, Gaudin JC, Chobert JM, Burova TV, Holt C, Mcnae I, Sawyer L, Haertle T (2004) A recombinant C121S mutant of bovine $\beta$-lactoglobulin is more susceptible to peptic digestion and to denaturation by reducing agents and heating. Biochemistry 43:6312-6321

Jean K, Renan M, Famelart MH, Guyomarc'h F (2006) Structure and surface properties of the serum heatinduced protein aggregates isolated from heated skim milk. Int Dairy J 16:303-315

Jimenez-Flores R, Richardson T (1988) Genetic engineering of the caseins to modify the behavior of milk during processing: a review. J Dairy Sci 71:2640-2654

Ju ZY, Kilara A (1998a) Aggregation induced by calcium chloride and subsequent thermal gelation of whey protein isolate. J Dairy Sci 81:925-931

Ju ZY, Kilara A (1998b) Effects of preheating on properties of aggregates and of cold-set gels of whey protein isolate. J Agric Food Chem 46:3604-3608

Jung J-M, Savin G, Pouzot M, Schmitt C, Mezzenga R (2008) Structure of heat-induced $\beta$-lactoglobulin aggregates and their complexes with sodium-dodecyl sulfate. Biomacromolecules 9:2477-2486

Kalab M, Allan-Wojtas P, Phipps-Todd BE (1983) Development of microstructure in set-style nonfat yoghurt. A review. Food Microstruct 2:51-66

Kehoe JJ, Morris ER, Brodkorb A (2007) The influence of bovine serum albumin on $\beta$-lactoglobulin denaturation, aggregation and gelation. Food Hydrocoll 21:747-755

Kella NKD, Yang ST, Kinsella JE (1989) Effect of disulfide bond-cleavage on structural and interfacial properties of whey proteins. J Agric Food Chem 37:1203-1210

Kerstens S, Murray BS, Dickinson E (2005) Confocal microscopy of heat-induced aggregation and gelation of $\beta$-lactoglobulin in presence of non-ionic surfactant. Food Hydrocoll 19:625-633

Khodarahmi R, Beyrami M, Soori H (2008) Appraisal of casein's inhibitory effects on aggregation accompanying carbonic anhydrase refolding and heat-induced ovalbumin fibrillogenesis. Arch Biochem Biophys 477:67-76

Kim SC, Olson NF, Richardson T (1990) Polymerization and gelation of thiolated $\beta$-lactoglobulin at ambient temperature induced by oxidation by potassium iodate. Milchwissenschaft 45:627-631

Koudelka T, Hoffmann P, Carver JA (2009) Dephosphorylation of $\alpha(\mathrm{s})$ - and $\beta$-Caseins and its effect on chaperone activity: a structural and functional investigation. J Agric Food Chem 57:5956-5964

Krasaekoopt W, Bhandari B, Deeth H (2003) Yogurt from UHT milk: a review. Aust J Dairy Technol 58:26-29

Kyte J, Doolittle RF (1982) A simple method for displaying the hydropathic character of a protein. J Mol Biol 157:105-132

Le Bon C, Nicolai T, Durand D (1999) Kinetics of aggregation and gelation of globular proteins after heatinduced denaturation. Macromolecules 32:6120-6127

Lee S-P, Cho Y, Batt CA (1993) Enhancing the gelation of $\beta$-lactoglobulin. J Agric Food Chem 41:13431348

Lee S-P, Kim D-S, Watkins S, Batt CA (1994) Reducing whey syneresis in yogurt by the addition of a thermolabile variant of $\beta$-lactoglobulin. Biosci Biotechnol Biochem 58:309-313

Lefebvre-Cases E, Gastaldi E, Vidal V, Marchesseau S, Lagaude A, Cuq J-L, Tarodo de la Fuente B (1998) Identification of interactions among casein gels using dissociating chemical agents. J Dairy Sci 81:932-938

Leonil J, Henry G, Jouanneau D, Delage MM, Forge V, Putaux JL (2008) Kinetics of fibril formation of bovine $\mathrm{K}$-casein indicate a conformational rearrangement as a critical step in the process. $\mathrm{J}$ Mol Biol 381:1267-1280

Li J, Dalgleish DG (2006) Controlled proteolysis and the properties of milk gels. J Agric Food Chem $54: 4687-4695$

Lieske B (1999) Effects of succinylation on selected physico-chemical properties of native casein micelles in milk. Milchwissenschaft 54:623

Lillard JS, Clare DA, Daubert CR (2009) Glycosylation and expanded utility of a modified whey protein ingredient via carbohydrate conjugation at low $\mathrm{pH}$. J Dairy Sci 92:35-48

Lorenzen PC, Neve H, Mautner A, Schlimme E (2002) Effect of enzymatic cross-linking of milk proteins on functional properties of set-style yughurt. Int J Dairy Technol 55:152-157

Lucey JA, Teo CT, Munro PA, Singh H (1997a) Rheological properties at small (dynamic) and large (yield) deformations of acid gels made from heated milk. J Dairy Res 64:591-600

Lucey JA, van Vliet T, Grolle K, Geurts T, Walstra P (1997b) Properties of acid casein gels made by acidification with glucono-delta-lactone. I. Rheological properties. Int Dairy J 7:381-388

Lucey JA, van Vliet T, Grolle K, Geurts T, Walstra P (1997c) Properties of acid casein gels made by acidification with glucono-delta-lactone. II. Syneresis, permeability and microstructural properties. Int Dairy J 7:389-397 
Lucey JA, Tamehana M, Singh H, Munro PA (1998a) Effect of interactions between denatured whey proteins and casein micelles on the formation and rheological properties of acid skim milk gels. J Dairy Res 65:555-567

Lucey JA, Teo CT, Munro PA, Singh H (1998b) Microstructure, permeability and appearance of acid gels made from heated skim milk. Food Hydrocoll 12:159-165

Lucey JA, Munro PA, Singh H (1999) Effects of heat treatment and whey protein addition on the rheological properties and structure of acid skim milk gels. Int Dairy J 9:275-279

Lucey JA, Tamehana M, Singh H, Munro PA (2000) Rheological properties of milk gels formed by a combination of rennet and glucono- $\delta$-lactone. J Dairy Res 67:415-427

Mahmoudi N, Mehalebi S, Nicolai T, Durand D, Riaublanc A (2007) Light-scattering study of the structure of aggregates and gels formed by heat-denatured whey protein isolate and $\beta$-lactoglobulin at neutral pH. J Agric Food Chem 55:3104-3111

Martin F, Cayot N, Marin A, Journaux L, Cayot P, Gervais P, Cachon R (2009) Effect of oxidoreduction potential and of gas bubbling on rheological properties and microstructure of acid skim milk gels acidified with glucono-delta-lactone. J Dairy Sci 92:5898-5906

Matsudomi N, Oshita T, Kobayashi K, Kinsella JE (1993) $\alpha$-lactalbumin enhances the gelation properties of bovine serum albumin. J Agric Food Chem 41:1053-1057

Matsudomi N, Kanda Y, Yoshika Y, Moriwaki H (2004) Ability of $\alpha_{\text {s-casein to suppress the heat }}$ aggregation of ovotransferrin. J Agric Food Chem 52:4882-4886

Mc Mahon DJ, Yousif BH, Kaláb M (1993) Effect of whey protein denaturation on structure of casein micelles and their rennetability after ultra-high temperature processing of milk with or without ultrafiltration. Int Dairy J 3:239-256

Mehalebi S, Nicolai T, Durand D (2008) Light scattering study of heat-denatured globular protein aggregates. Int J Biol Macromol 43:129-135

Menard O, Camier B, Guyomarc'h F (2005) Effect of heat treatment at alkaline pH on the rennet coagulation properties of skim milk. Lait 85:515-526

Mine Y (1996) Laser light scattering study on the heat-induced ovalbumin aggregates related to its gelling property. J Agric Food Chem 44:2086-2090

Mollé D, Jean K, Guyomarc'h F (2006) Chymosin sensitivity of the heat-induced serum protein aggregates isolated from skim milk. Int Dairy J 16:1435-1441

Morgan F, Venien A, Bouhallab S, Molle D, Leonil J, Peltre G, Levieux D (1999) Modification of bovine $\beta$-lactoglobulin by glycation in a powdered state or in an aqueous solution: immunochemical characterization. J Agric Food Chem 47:4543-4548

Morgan PE, Treweek TM, Lindner RA, Price WE, Carver JA (2005) Casein proteins as molecular chaperones. J Agric Food Chem 53:2670-2683

Morr CV (1985) Functionality of heated milk-proteins in dairy and related foods. J Dairy Sci 68:27732781

Mottar J, Bassier A, Joniau M, Baert J (1989) Effect of heat-induced association of whey proteins and casein micelles on yogurt texture. J Dairy Sci 72:2247-2256

Mounsey JS, O'Kennedy BT (2007) Conditions limiting the influence of thiol-disulphide interchange reactions on the heat-induced aggregation kinetics of $\beta$-lactoglobulin. Int Dairy J 17:1034-1042

Murphy MC, Howell NK (1990) Effect of succinylation on the functional and physicochemical properties of bovine serum-albumin. J Sci Food Agric 51:109-123

Nabi N, Britten M, Paquin P (2000) Soluble polymers obtained by thermal denaturation of whey protein isolate: effect of hydrogen peroxide. Milchwissenschaft 55:86-89

Nigen M, Croguennec T, Madec MN, Bouhallab S (2007) Apo $\alpha$-lactalbumin and lysozyme are colocalized in their subsequently formed spherical supramolecular assembly. FEBS J 274:60856093

Nigen M, Croguennec T, Bouhallab S (2009) Formation and stability of $\alpha$-lactalbumin-lysozyme spherical particles: involvement of electrostatic forces. Food Hydrocoll 23:510-518

Niki R, Ito T, Motoshima H, Watanabe T, Tsukasaki F (2003) Effects of pretreating milk with rennet on the viscoelastic properties and the microstructure of acid-induced milk gels. Milchwissenschaft 58:595-598

Noh B, Richardson T, Creamer LK (1989) Radiolabelling of the heat-induced interactions between $\alpha$ lactalbumin, $\beta$-lactoglobulin and $\mathrm{K}$-casein in milk and in buffer solutions. J Food Sci 54:889-893

O'Connell JE, Fox PF (2001) Effect of $\beta$-lactoglobulin and precipitation of calcium phosphate on the thermal coagulation of milk. J Dairy Res 68:81-94

O'Kennedy BT, Kelly PM (2000) Evaluation of milk protein interactions during acid gelation using a simulated yoghurt model. Milchwissenschaft 55:187-190 
O'Kennedy BT, Mounsey JS (2006) Control of heat-induced aggregation of whey proteins using casein. J Agric Food Chem 54:5637-5642

O'Kennedy BT, Mounsey JS (2009) The dominating effect of ionic strength on the heat-induced denaturation and aggregation of $\beta$-lactoglobulin in simulated milk ultrafiltrate. Int Dairy J 19:123-128

Oldfield DJ, Singh H, Taylor MW (1998a) Association of $\beta$-lactoglobulin and $\alpha$-lactalbumin with the casein micelles in skim milk heated in an ultra-high temperature plant. Int Dairy J 8:765-770

Oldfield DJ, Singh H, Taylor MW, Pearce KN (1998b) Kinetics of denaturation and aggregation of whey proteins in skim milk heated in an ultra-high temperature (UHT) pilot plant. Int Dairy J 8:311-318

Oldfield DJ, Taylor MW, Singh H (2005) Effect of preheating and other process parameters on whey protein reactions during skim milk powder manufacture. Int Dairy J 15:501-511

Oliver CM, Melton LD, Stanley RA (2006) Creating proteins with novel functionality via the Maillard reaction: a review. Crit Rev Food Sci Nutr 46:337-350

Otte J, Ipsen R, Bauer R, Bjerrum MJ, Waninge R (2005) Formation of amyloid-like fibrils upon limited proteolysis of bovine $\alpha$-lactalbumin. Int Dairy J 15:219-229

Ozcan-Yilsay T, Lucey JA, Horne DS (2008) Effect of tetrasodium pyrophosphate on the physicochemical properties of yogurt gels. J Dairy Sci 91:4492-4500

Parnell-Clunies E, Kakuda Y, Smith AK (1987) Microstructure of yogurt as affected by heat treatment of milk. Milchwissenschaft 42:413-417

Parris N, Hollar CM, Hsieh A, Cockley KD (1997) Thermal stability of whey protein concentrate mixtures: aggregates formation. J Dairy Sci 80:19-28

Peri C, Pagliarini E, Iametti S, Bonomi F (1990) A study of surface hydrophobicity of milk proteins during enzymic coagulation and curd hardening. J Dairy Res 57:101-108

Pouzot M, Nicolai T, Visschers RW, Weijers M (2005) X-ray and light scattering study of the structure of large protein aggregates at neutral pH. Food Hydrocoll 19:231-238

Puvanenthiran A, Williams RPW, Augustin MA (2002) Structure and visco-elastic properties of set yoghurt with altered casein to whey protein ratios. Int Dairy J 12:383-391

Ramasubramanian L, Restuccia C, Deeth HC (2008) Effect of calcium on the physical properties of stirred probiotic yogurt. J Dairy Sci 91:4164-4175

Rasmussen P, Barbiroli A, Bonomi F, Faoro F, Ferranti P, Iriti M, Picariello G, Iametti S (2007) Formation of structured polymers upon controlled denaturation of $\beta$-lactoglobulin with different chaotropes. Biopolymers 86:57-72

Relkin P (1998) Reversibility of heat-induced conformational changes and surface exposed hydrophobic clusters of $\beta$-lactoglobulin: their role in heat-induced sol-gel transition. Int J Biol Macromol 22:5966

Renan M, Mekmene O, Famelart MH, Guyomarc'h F, Arnoult-Delest V, Paquet D, Brulé G (2006) pHdependent behavior of soluble protein aggregates formed during heat treatment of milk at $\mathrm{pH} 6.5$ or 7.2. J Dairy Res 73:79-86

Renan M, Guyomarc'h F, Chatriot M, Gamerre V, Famelart MH (2007) Limited enzymatic treatment of skim milk using chymosin affects the micelle/serum distribution of the heat-induced whey protein/Kcasein aggregates. J Agric Food Chem 55:6736-6745

Risso PH, Gatti CA, Zerpa SM, Perez GR (2000) Comparative study of the action of anionic and nonionic hydrophobic fluorescent markers on the enzymic coagulation of heated bovine casein micelles. Food Hydrocoll 14:179-185

Robitaille G, Ayers C (1995) Effects of k-casein glycosylation on heat-stability of milk. Food Res Int 28:17-21

Robitaille G, Ng-Kwai-Hang K-F, Monardes HG (1991) Variation in the N-acetyl neuraminic acid content of bovine K-casein. J Dairy Res 58:107-114

Rodriguez del Angel C, Dalgleish DG (2006) Structures and some properties of soluble protein complexes formed by the heating of reconstituted skim milk powder. Food Res Int 39:472-479

Roefs SPFM, van Vliet T (1990) Structure of acid casein gels. 2. Dynamic measurements and type of interaction forces. Colloids Surf 50:161-175

Roefs SPFM, de Groot-Mostert AEA, van Vliet T (1990) Structure of acid casein gels. 1. Formation and model of gel network. Colloids Surf 50:141-159

Roesch RR, Corredig M (2005) Heat-induced soy-whey proteins interactions: formation of soluble and insoluble protein complexes. J Agric Food Chem 53:3476-3482

Roesch R, Corredig M (2006) Study of the effect of soy proteins on the acid-induced gelation of casein micelles. J Agric Food Chem 54:8236-8243

Roesch RR, Juneda M, Monagle C, Corredig M (2004) Aggregation of soy/milk mixes during acidification. Food Res Int 37:209-215 
Sackett DL, Wolff J (1987) Nile red as a polarity-sensitive fluorescent-probe of hydrophobic protein surfaces. Anal Biochem 167:228-234

Sandoval-Castilla O, Lobato-Calleros C, Guirre-Mandujano E, Vernon-Carter EJ (2004) Microstructure and texture of yogurt as influenced by fat replacers. Int Dairy J 14:151-159

Schmitt C, Bovay C, Vuilliomenet AM, Rouvet M, Bovetto L, Barbar R, Sanchez C (2009) Multiscale characterization of individualized $\beta$-lactoglobulin microgels formed upon heat treatment under narrow pH range conditions. Langmuir 25:7899-7909

Schokker EP, Singh H, Creamer LK (2000) Heat-induced aggregation of $\beta$-lactoglobulin A and B with $\alpha$ lactalbumin. Int Dairy J 10:843-853

Schorsch C, Wilkins DK, Jones MJ, Norton IT (2001) Gelation of casein-whey mixtures: effects of heating whey proteins alone or in the presence of casein micelles. J Dairy Res 68:471-481

Sherwin CP, Foegeding EA (1997) The effects of $\mathrm{CaCl}_{2}$ on aggregation of whey proteins. Milchwissenschaft 52:93-96

Simons JWFA, Kosters HA, Visschers RW, De Jongh HHJ (2002) Role of calcium as trigger in thermal $\beta$ lactoglobulin aggregation. Arch Biochem Biophys 406:143-152

Sitohy M, Chobert JM, Popineau Y, Haertle T (1995) Functional properties of $\beta$-lactoglobulin phosphorylated in the presence of different aliphatic amines. Lait 75:503-512

Smits P, van Brouwershaven JH (1980) Heat-induced association of $\beta$-lactoglobulin and casein micelles. J Dairy Res 47:313-325

Stevenson EM, Law AJR, Leaver J (1996) Heat-induced aggregation of whey proteins is enhanced by addition of thiolated $\beta$-casein. J Agric Food Chem 44:2825-2828

Surel O, Famelart MH (2003) Heat induced gelation of acid milk: balance between weak and covalent bonds. J Dairy Res 70:253-256

Takase K (1998) Reactions of denatured proteins with other cellular components to form insoluble aggregates and protection by lactoferrin. FEBS Lett 441:271-274

Thorn DC, Meehan S, Sunde M, Rekas A, Gras SL, MacPhee CE, Dobson CM, Wilson MR, Carver JA (2005) Amyloid fibril formation by bovine milk K-casein and its inhibition by the molecular chaperones $\alpha(\mathrm{s}-)$ and $\beta$-casein. Biochemistry 44:17027-17036

Thorn DC, Ecroyd H, Carver JA (2009) The two-faced nature of milk casein proteins: amyloid fibril formation and chaperone-like activity. Aust J Dairy Technol 64:34-40

Tran Le T, El-Bakry M, Neirynck N, Bogus M, Dinh Hoa H, Van der Meeren P (2007) Hydrophilic lecithins protect milk proteins against heat-induced aggregation. Colloids Surf B 60:167-173

Tuinier R, de Kruif CG (2002) Stability of casein micelles in milk. J Chem Phys 117:1290-1295

Unterhaslberger G, Schmitt C, Sanchez C, Appolonia-Nouzille C, Raemy A (2006) Heat-denaturation and aggregation of $\beta$-lactoglobulin enriched WPI in the presence of arginine $\mathrm{HCl}, \mathrm{NaCl}$ and guanidinium $\mathrm{HCl}$ at $\mathrm{pH} 4.0$ and 7.0. Food Hydrocoll 20:1006-1019

van Boekel MAJS, Walstra P (1995) Use of kinetics in studying heat-induced changes in foods. In: Fox PF (ed) Heat-induced changes in milk. International Dairy Federation, Brussels, Belgium, pp 22-50

van Vliet T, Walstra P (1994) Water in casein gels; how to get it out or keep it in. J Food Eng 22:75-88

van Vliet T, Roefs SPFM, Zoon P, Walstra P (1989) Rheological properties of casein gels. J Dairy Res 56:529-534

van Vliet T, van Dijk HJM, Zoon P, Walstra P (1991) Relation between syneresis and rheological properties of particle gels. Colloid Polym Sci 269:620-627

van Vliet T, Lakemond CMM, Visschers RW (2004) Rheology and structure of milk protein gels. Curr Opin Coll Interface Sci 9:298-304

Vardhanabhuti B, Foegeding EA, Mc Guffey MK, Daubert CR, Swaisgood HE (2001) Gelation properties of dispersions containing polymerized and native whey protein isolate. Food Hydrocoll 15:165-175

Vasbinder AJ, de Kruif CG (2003) Casein-whey interactions in heated milk: the influence of pH. Int Dairy J 13:669-677

Vasbinder AJ, Alting AC, Visschers RW, de Kruif CG (2003) Texture of acid milk gels: formation of disulfide cross-links during acidification. Int Dairy J 13:29-38

Vasbinder AJ, van de Velde F, de Kruif CG (2004) Gelation of casein-whey protein mixtures. J Dairy Sci $87: 1167-1176$

Veerman C, Baptist H, Sagis LMC, van der Linden E (2003) A new multistep $\mathrm{Ca}^{2+}$-induced cold gelation process for $\beta$-lactoglobulin. J Agric Food Chem 51:3880-3885

Verheul M, Roefs SPFM, de Kruif CG (1998) Kinetics of heat-induced aggregation of $\beta$-lactoglobulin. J Agric Food Chem 46:896-903

Vidal V, Marchesseau S, Lagaude A, Cuq J-L (1998) Influence of chemical agents on casein interactions in dairy products: chemical modification of milk proteins. Colloids Surf B 12:7-14 
Vreeman HJ, Visser J, Slangen CJ, Van Riel JAM (1986) Characterization of bovine K-casein fractions and the kinetics of chymosin-induced macropeptide release from carbohydrate-free and carbohydratecontaining fractions determined by high-performance gel-permeation chromatography. Biochem $\mathrm{J}$ 240:87-97

Walstra P (1990) On the stability of casein micelles. J Dairy Sci 73:1965-1979

Walstra P (2003a) Bonds and interaction forces. In: Walstra P (ed) Physical chemistry of foods. Marcel Dekker, New-York, USA, pp 46-58

Walstra P (2003b) Reaction kinetics. In: Walstra P (ed) Physical chemistry of foods. Marcel Dekker, NewYork, USA, pp 59-86

Walstra P, Jenness R (1984) Heating. In: Walstra P, Jenness R (eds) Dairy chemistry and physics. Wiley, New York, USA, pp 162-185

Wanatabe K, Klostermeyer H (1976) Heat-induced changes in sulphydryl and disulphide levels of $\beta$ lactoglobulin A and the formation of polymers. J Dairy Res 43:411-418

Weijers M, Broersen K, Barneveld PA, Stuart MAC, Hamer RJ, De Jongh HJ, Visschers RW (2008) Net charge affects morphology and visual properties of ovalbumin aggregates. Biomacromolecules 9:3165-3172

Xiong YL (1992) Influence of $\mathrm{pH}$ and ionic environment on thermal aggregation of whey proteins. J Agric Food Chem 40:380-384

Xu D, Lin SL, Nussinov R (1997) Protein binding versus protein folding: the role of hydrophilic bridges in protein associations. J Mol Biol 265:68-84

Yong Y, Foegeding E (2010) Caseins: utilizing molecular chaperone properties to control protein aggregation in foods. J Agric Food Chem 58:685-693

Zhang X, Fu X, Zhang H, Liu C, Jiao W, Chang Z (2005) Chaperone-like activity of $\beta$-casein. Int J Biochem Cell Biol 37:1232-1240

Zhou P, Liu X, Labuza TP (2008) Moisture-induced aggregation of whey proteins in a protein/buffer model system. J Agric Food Chem 56:2048-2054 